\title{
11. SEISMIC VELOCITIES AND ELASTIC PROPERTIES OF OCEANIC GABBROIC ROCKS FROM HOLE 735B 1
}

\author{
Gerardo J. Iturrino, ${ }^{2,3}$ Nikolas I. Christensen, ${ }^{2}$ Stephen Kirby, ${ }^{4}$ and Matthew H. Salisbury ${ }^{5}$
}

\begin{abstract}
The nearly continuous recovery of $0.5 \mathrm{~km}$ of generally fresh, layer 3 gabbroic rocks at Hole $735 \mathrm{~B}$, especially near the bottom of the section, presents scientists an unusual opportunity to study the detailed elastic properties of the lower oceanic crust. Extending compressional-wave and density shipboard measurements at room pressure, $V_{p}$ and $V_{s}$ were measured at pressures from 20 to $200 \mathrm{MPa}$ using the pulse transmission method. All of the rocks exhibit significant increases in velocity with increasing pressure up to about $150 \mathrm{MPa}$, a feature attributed to the closing of microcrack porosity. Measured velocities reflect the mineralogical makeup and microstructures acquired during the tectonic history of Hole 735B. Most of the undeformed and unaltered gabbros are approximately 65:35 plagioclase/ clinopyroxene rocks plus olivine or oxide minerals, and the observed densities and velocities are fully consistent with the Voigt-Reuss-Hill (VRH) averages of the component minerals and their proportions. Depending on their olivine content, the predominant olivine gabbros at $200 \mathrm{MPa}$ have average $V_{p}=7.1 \pm 0.2 \mathrm{~km} / \mathrm{s}, V_{s}=3.9 \pm 0.1 \mathrm{~km} / \mathrm{s}$, and grain densities of $2.95 \pm 0.5 \mathrm{~g} / \mathrm{cm}^{3}$. The less abundant iron-titanium (Fe-Ti) oxide gabbros average $V_{p}=6.75$ $\pm 0.15 \mathrm{~km} / \mathrm{s}, V_{s}=3.70 \pm 0.1 \mathrm{~km} / \mathrm{s}$, and grain densities of $3.22 \pm 0.05 \mathrm{~g} / \mathrm{cm}^{3}$, reflecting the higher densities and lower velocities of oxide minerals compared to olivine. About $30 \%$ of the core is plastically deformed, and the densities and directionally averaged velocities of these shear-zone tectonites are generally consistent with those of the gabbros, their protoliths. Three sets of observations indicate that the shear-zone metagabbros are elastically anisotropic: (1) directional variations in $V_{p}$, both vertical and horizontal and with respect to foliation and lineation; (2) discrepancies among $V_{p}$ values for the horizontal cores and the VRH averages of the component minerals and their mineral proportions, suggesting preferred crystallographic orientations of anisotropic minerals; and (3) variations of $V_{s}$ of up to $7 \%$, with polarization directions parallel and perpendicular to foliation. Optical inspection of thin sections of the same samples indicates that plagioclase feldspar, clinopyroxene, and amphibole typically display crystallographic-preferred orientations, and this, plus the elastic anisotropy of these minerals, suggests that preferred orientations are responsible for much of the observed anisotropy, particularly at high pressure. Alteration tends to be localized to brittle faults and brecciated zones, and typical alteration minerals are amphibole and secondary plagioclase, which do not significantly change the velocity-density relationships.
\end{abstract}

\section{INTRODUCTION}

Compressional- and shear-wave velocities $\left(V_{p}\right.$ and $\left.V_{s}\right)$ were measured as functions of confining pressure for the gabbros from Hole 735B. These data provide important constraints on the interpretation of seismic data from the Atlantis II Fracture Zone. The extent of crack porosity may be estimated from sonic log and vertical seismic profiling (VSP) velocities, when these are compared with the laboratory results. Also, refraction and reflection data may be interpreted in terms of compositional variations on the basis of laboratory $V_{p}$ and $V_{s}$ measurements. Finally, acoustic impedance contrasts may be calculated from laboratory velocity and density data and used for generating synthetic seismograms to help interpret reflection profiles.

In the following sections, emphasis has been placed on correlating seismic velocities with the physical and chemical properties of the core samples from Hole 735B. Anisotropy is becoming more important in the interpretation of oceanic seismic data (Stephen, 1981; White and Whitmarsh, 1984; and

1 Von Herzen, R. P., Robinson, P. T.,et al., 1991. Proc. ODP, Sci. Results, 118: College Station, TX (Ocean Drilling Program).

2 Rock Physics Laboratory, Department of Earth and Atmospheric Sciences, Purdue University, West Lafayette, IN 47907.

${ }^{3}$ Rosenstiel School of Marine and Atmosphere Science, Marine Geology and Geophysics, 4600 Rickenbacker Causeway, Miami, FL 33149.

${ }^{4}$ Branch of Tectonophysics, U.S. Geological Survey, MS 977 , Menlo Park, CA 94205 .

${ }^{5}$ Geological Survey of Canada, Dartmouth, Nova Scotia, Canada, B2H 4A2.
Shearer and Orcutt, 1985, 1986); hence, the directional dependence of compressional-wave velocities as well as shear-wave splitting in the gabbros, is examined in detail. In addition to anisotropy, alteration and porosity are shown to be important parameters controlling seismic velocities in gabbros. Velocitydensity relationships and the elastic constants are also examined in detail.

\section{PHYSICAL PROPERTIES}

The mineralogical makeup, crack porosity, density, alteration, and mineral orientation of oceanic rocks are among the important characteristics responsible for significant variations in seismic velocities throughout the oceanic crust. Bècause velocities at in-situ pressures are often different from measurements at atmospheric pressure (Birch, 1960), it is important that velocity data used for crustal studies be obtained at elevated pressures. For example, seismic anisotropy can originate from preferred mineral and crack orientations. Hydrostatic velocity measurements at $200 \mathrm{MPa}$ minimize the effects of cracks on the velocities by closing the intergranular pore spaces and fracture openings, thus providing information about preferred mineral orientation in the lower oceanic crust.

The drill core was cut along its axis on board the ship, while horizontal and vertical minicores were drilled normal and parallel, respectively, to the drill core. $V_{p}$ and $V_{s}$ as functions of confining pressure of dry samples were determined by the pulse transmission method (Birch, 1960; Christensen, 1965, 1985), and results are presented in Table 1. Birch's method determines the traveltime of an elastic wave in a rock cylinder of known length and yields velocity determi- 
Table 1. Variations in compressional- and shear-wave velocities with direction (evidence for anisotropy).

\begin{tabular}{|c|c|c|c|c|c|c|c|c|c|}
\hline \multirow{2}{*}{$\begin{array}{l}\text { Core, section, interval } \\
\text { (cm) }\end{array}$} & \multirow{2}{*}{$\begin{array}{l}\text { Rock } \\
\text { type }\end{array}$} & \multirow{2}{*}{$\begin{array}{l}\text { Density } \\
\left(\mathrm{g} / \mathrm{cm}^{3}\right)\end{array}$} & \multirow[b]{2}{*}{ Mode } & \multicolumn{3}{|c|}{ Velocity $(\mathrm{km} / \mathrm{s})$} & Pre & sure $(\mathrm{A}$ & Pa) \\
\hline & & & & 20 & 40 & 60 & 80 & 100 & 200 \\
\hline $118-735 \mathrm{~B}-2 \mathrm{D}-1,64-74 \mathrm{v}$ & FM & 2.892 & $\mathrm{P}$ & 6.44 & 6.52 & 6.57 & 6.60 & 6.63 & 6.70 \\
\hline $2 \mathrm{D}-1,113-115 \mathrm{~h}$ & FM & 3.101 & $P$ & 5.94 & 6.02 & 6.07 & 6.10 & 6.13 & 6.21 \\
\hline & & & Sp & 3.49 & 3.53 & 3.56 & 3.58 & 3.60 & 3.64 \\
\hline & & & So & 3.30 & 3.33 & 3.35 & 3.37 & 3.38 & 3.41 \\
\hline $2 \mathrm{D}-1,139-141 \mathrm{~h}$ & PMy & 2.918 & $\mathbf{P}$ & 6.39 & 6.46 & 6.51 & 6.54 & 6.56 & 6.61 \\
\hline $4 \mathrm{D}-2,7-9 \mathrm{~h}$ & $\mathrm{PM}$ & 2.876 & $\mathrm{P}$ & 6.36 & 6.43 & 6.48 & 6.52 & 6.54 & 6.60 \\
\hline & & & Sp & 3.72 & 3.76 & 3.79 & 3.82 & 3.83 & 3.90 \\
\hline & & & So & 3.56 & 3.61 & 3.64 & 3.66 & 3.67 & 3.70 \\
\hline $9 D-1,110-115 v$ & My & 2.737 & $\mathrm{P}$ & 5.49 & 5.59 & 5.66 & 5.70 & 5.74 & 5.83 \\
\hline $9 \mathrm{D}-1,120-122 \mathrm{~h}$ & My & 2.971 & $\mathrm{P}$ & 6.86 & 6.91 & 6.94 & 6.97 & 6.99 & 7.04 \\
\hline & & & So & 3.80 & 3.83 & 3.84 & 3.85 & 3.86 & 3.88 \\
\hline 10D-1, 24-26h & My & 3.035 & $P$ & 6.83 & 6.90 & 6.95 & 6.98 & 7.01 & 7.09 \\
\hline & & & Sp & 3.89 & 3.91 & 3.93 & 3.94 & 3.95 & 3.97 \\
\hline & & & So & 3.82 & 3.84 & 3.86 & 3.87 & 3.88 & 3.91 \\
\hline $10 \mathrm{D}-1,32-37 v$ & My & 3.011 & $\mathbf{P}$ & 6.74 & 6.81 & 6.86 & 6.90 & 6.93 & 7.00 \\
\hline $12 \mathrm{R}-1,36-39 \mathrm{~h}$ & PG & 2.988 & $\mathbf{P}$ & 6.46 & 6.56 & 6.61 & 6.65 & 6.68 & 6.77 \\
\hline $12 \mathrm{R}-3,8-10 \mathrm{~h}$ & $\operatorname{Tr}$ & 2.886 & $\mathrm{P}$ & 6.52 & 6.62 & 6.68 & 6.72 & 6.74 & 6.80 \\
\hline $13 \mathrm{R}-2,55-58 \mathrm{~h}$ & PM & 2.897 & $P$ & 6.83 & 6.89 & 6.94 & 6.97 & 6.99 & 7.07 \\
\hline $13 \mathrm{R}-3,120-124 \mathrm{v}$ & PM & 2.892 & $\mathbf{P}$ & 6.76 & 6.87 & 6.93 & 6.97 & 6.98 & 7.06 \\
\hline $13 \mathrm{R}-3,131-134 \mathrm{~h}$ & PM & 2.862 & $\mathrm{P}$ & 6.77 & 6.87 & 6.93 & 6.97 & 6.99 & 7.04 \\
\hline $14 \mathrm{R}-1,35-38 \mathrm{~h}$ & My & 3.024 & $P$ & 6.59 & 6.66 & 6.71 & 6.74 & 6.77 & 6.84 \\
\hline & & & Sp & 3.74 & 3.77 & 3.79 & 3.80 & 3.81 & 3.83 \\
\hline & & & So & 3.65 & 3.73 & 3.78 & 3.82 & 3.84 & 3.90 \\
\hline $14 \mathrm{R}-1,48-53 \mathrm{v}$ & My & 2.720 & $\mathrm{P}$ & 7.20 & 7.26 & 7.30 & 7.33 & 7.35 & 7.41 \\
\hline $15 \mathrm{R}-2,128-130 \mathrm{~h}$ & My & 2.856 & $\mathrm{P}$ & 6.31 & 6.39 & 6.44 & 6.48 & 6.51 & 6.61 \\
\hline & & & $\mathrm{Sp}$ & 3.73 & 3.76 & 3.78 & 3.79 & 3.80 & 3.83 \\
\hline & & & So & 3.69 & 3.72 & 3.73 & 3.74 & 3.75 & 3.78 \\
\hline $15 R-2,136-141 v$ & My & 2.843 & $\mathrm{P}$ & 6.32 & 6.39 & 6.43 & 6.46 & 6.48 & 6.57 \\
\hline $16 \mathrm{R}-4,24-26 \mathrm{~h}$ & AMy & 2.843 & $\mathrm{P}$ & 6.85 & 6.90 & 6.94 & 6.96 & 6.98 & 7.05 \\
\hline $16 \mathrm{R}-4,39-43 \mathrm{v}$ & AMy & 2.868 & $\mathrm{P}$ & 6.44 & 6.50 & 6.53 & 6.56 & 6.58 & 6.64 \\
\hline $16 \mathrm{R}-5,24-26 \mathrm{~h}$ & $\mathrm{MMg}$ & 2.916 & $\mathrm{P}$ & 6.60 & 6.69 & 6.74 & 6.78 & 6.81 & 6.91 \\
\hline $18 \mathrm{R}-3,29-31 \mathrm{~h}$ & $\mathrm{MMg}$ & 2.925 & $\mathbf{P}$ & 6.60 & 6.68 & 6.74 & 6.78 & 6.81 & 6.89 \\
\hline $20 \mathrm{R}-2,39-44 \mathrm{v}$ & PM & 2.874 & $\mathrm{P}$ & 6.93 & 7.03 & 7.10 & 7.13 & 7.16 & 7.22 \\
\hline $20 \mathrm{R}-2,54-56 \mathrm{~h}$ & PM & 2.950 & $P$ & 6.86 & 6.95 & 7.01 & 7.05 & 7.07 & 7.14 \\
\hline & & & Sp & 3.93 & 4.02 & 4.08 & 4.11 & 4.13 & 4.19 \\
\hline & & & So & 3.89 & 3.96 & 4.01 & 4.04 & 4.06 & 4.12 \\
\hline 23R-2 34-36h & OG & 2.937 & $\mathbf{P}$ & 6.83 & 6.93 & 7.00 & 7.05 & 7.08 & 7.16 \\
\hline & & & $S$ & 3.75 & 3.78 & 3.80 & 3.82 & 3.83 & 3.86 \\
\hline $23 \mathrm{R}-4,120-122 \mathrm{~h}$ & $\mathrm{Ba}$ & 2.929 & $\mathrm{P}$ & 5.64 & 5.73 & 5.78 & 5.80 & 5.83 & 5.98 \\
\hline $24 \mathrm{R}-3,50-52 \mathrm{~h}$ & FM & 2.929 & $\mathrm{P}$ & 6.35 & 6.43 & 6.49 & 6.53 & 6.56 & 6.66 \\
\hline & & & Sp & 3.63 & 3.67 & 3.69 & 3.71 & 3.73 & 3.77 \\
\hline & & & So & 3.57 & 3.61 & 3.63 & 3.64 & 3.65 & 3.69 \\
\hline $25 \mathrm{R}-3,119-122 \mathrm{~h}$ & OG & 2.850 & $\mathrm{P}$ & 6.83 & 6.95 & 6.99 & 7.02 & 7.04 & 7.10 \\
\hline $26 \mathrm{R}-1,62-64 \mathrm{~h}$ & OG & 2.928 & $\mathrm{P}$ & 6.60 & 6.69 & 6.74 & 6.78 & 6.80 & 6.87 \\
\hline & & & $\mathbf{S}$ & 3.76 & 3.81 & 3.83 & 3.85 & 3.87 & 3.91 \\
\hline $27 \mathrm{R}-1,84-86 \mathrm{~h}$ & OG & 3.009 & $\mathrm{P}$ & 7.27 & 7.36 & 7.41 & 7.45 & 7.48 & 7.58 \\
\hline $28 \mathrm{R}-1,24-32 \mathrm{v}$ & FM & 2.850 & $\mathrm{P}$ & 6.19 & 6.30 & 6.36 & 6.41 & 6.44 & 6.54 \\
\hline $28 \mathrm{R}-1,34-37 \mathrm{~h}$ & FM & 2.798 & $\mathrm{P}$ & 5.95 & 6.06 & 6.13 & 6.18 & 6.22 & 6.35 \\
\hline $28 \mathrm{R}-2,2-8 \mathrm{v}$ & FM & 3.114 & $\mathrm{P}$ & 6.52 & 6.62 & 6.70 & 6.73 & 6.75 & 6.81 \\
\hline $28 \mathrm{R}-2,12-14 \mathrm{~h}$ & FM & 3.013 & $\mathrm{P}$ & 6.59 & 6.66 & 6.69 & 6.73 & 6.76 & 6.82 \\
\hline & & & Sp & 3.70 & 3.73 & 3.74 & 3.75 & 3.76 & 3.78 \\
\hline & & & So & 3.71 & 3.74 & 3.76 & 3.78 & 3.79 & 3.81 \\
\hline $30 \mathrm{R}-5,91-93 \mathrm{~h}$ & AnG & 2.879 & $\mathrm{P}$ & 6.41 & 6.48 & 6.53 & 6.56 & 6.59 & 6.67 \\
\hline & & & $\mathrm{S}$ & 3.65 & 3.68 & 3.70 & 3.71 & 3.72 & 3.75 \\
\hline $31 \mathrm{R}-2,120-122 \mathrm{~h}$ & PM & 2.930 & $\mathrm{P}$ & 6.73 & 6.81 & 6.86 & 6.90 & 6.92 & 6.99 \\
\hline & & & $\mathrm{S}$ & 3.77 & 3.81 & 3.84 & 3.85 & 3.87 & 3.91 \\
\hline $33 \mathrm{R}-4,129-131 \mathrm{~h}$ & OG & 2.897 & $\mathbf{P}$ & 6.53 & 6.60 & 6.65 & 6.68 & 6.71 & 6.79 \\
\hline & & & $\mathbf{S}$ & 3.77 & 3.80 & 3.82 & 3.83 & 3.84 & 3.88 \\
\hline $34 \mathrm{R}-1,104-105 \mathrm{~h}$ & $\mathrm{AMg}$ & 2.879 & $\mathrm{P}$ & 6.92 & 7.01 & 7.06 & 7.10 & 7.11 & 7.14 \\
\hline $40 \mathrm{R}-5,13-15 \mathrm{~h}$ & $\mathrm{FM}$ & 2.928 & $P$ & 6.69 & 6.76 & 6.79 & 6.81 & 6.82 & 6.85 \\
\hline & & & Sp & 3.73 & 3.77 & 3.80 & 3.82 & 3.83 & 3.85 \\
\hline $40 R-5,30-35 v$ & FM & 2.966 & $\mathrm{P}$ & 6.73 & 6.85 & 6.92 & 6.97 & 7.01 & 7.10 \\
\hline $42 \mathrm{R}-2,119-121 \mathrm{~h}$ & OG & 2.946 & $\mathrm{P}$ & 6.68 & 6.80 & 6.87 & 6.91 & 6.93 & 6.98 \\
\hline $42 \mathrm{R}-4,62-64 \mathrm{~h}$ & OG & 2.923 & $\mathrm{P}$ & 6.68 & 6.75 & 6.80 & 6.83 & 6.85 & 6.91 \\
\hline & & & $\mathrm{S}$ & 3.80 & 3.83 & 3.86 & 3.87 & 3.89 & 3.91 \\
\hline $43 \mathrm{R}-4,64-66 \mathrm{~h}$ & OG & 3.024 & $\mathrm{P}$ & 6.75 & 6.82 & 6.86 & 6.89 & 6.92 & 6.98 \\
\hline & & & $\mathrm{S}$ & 3.78 & 3.81 & 3.82 & 3.84 & 3.85 & 3.87 \\
\hline $45 \mathrm{R}-2,15-17 \mathrm{~h}$ & OG & 2.925 & $\mathbf{P}$ & 6.86 & 7.03 & 7.12 & 7.18 & 7.22 & 7.30 \\
\hline $46 \mathrm{R}-2,21-23 \mathrm{~h}$ & OG & 2.987 & $\mathrm{P}$ & 6.81 & 6.88 & 6.92 & 6.96 & 6.98 & 7.05 \\
\hline & & & $\mathrm{S}$ & 3.79 & 3.83 & 3.85 & 3.87 & 3.88 & 3.90 \\
\hline $46 \mathrm{R}-2,128-130 \mathrm{~h}$ & PM & 2.921 & $\mathrm{P}$ & 6.61 & 6.68 & 6.73 & 6.76 & 6.79 & 6.88 \\
\hline & & & $\mathrm{S}$ & 3.82 & 3.86 & 3.88 & 3.90 & 3.91 & 3.94 \\
\hline $48 \mathrm{R}-4,82-84 \mathrm{~h}$ & FTG & 3.288 & $\mathrm{P}$ & 6.61 & 6.69 & 6.73 & 6.77 & 6.79 & 6.89 \\
\hline & & & $\mathrm{Sp}$ & 3.74 & 3.78 & 3.81 & 3.83 & 3.84 & 3.88 \\
\hline $48 \mathrm{R}-4,86-90 \mathrm{v}$ & FTG & 3.265 & $\mathrm{P}$ & 6.64 & 6.70 & 6.74 & 6.76 & 6.79 & 6.85 \\
\hline $49 \mathrm{R}-2,89-91 \mathrm{~h}$ & FTG & 3.272 & $\mathrm{P}$ & 6.58 & 6.65 & 6.69 & 6.72 & 6.75 & 6.80 \\
\hline
\end{tabular}


Table 1 (continued).

\begin{tabular}{|c|c|c|c|c|c|c|c|c|c|}
\hline \multirow{2}{*}{$\begin{array}{l}\text { Core, section, interval } \\
(\mathrm{cm})\end{array}$} & \multirow{2}{*}{$\begin{array}{l}\text { Rock } \\
\text { type }\end{array}$} & \multirow{2}{*}{$\begin{array}{l}\text { Density } \\
\left(\mathrm{g} / \mathrm{cm}^{3}\right)\end{array}$} & \multirow[b]{2}{*}{ Mode } & \multicolumn{3}{|c|}{ Velocity $(\mathrm{km} / \mathrm{s})$} & \multicolumn{3}{|c|}{ Pressure (MPa) } \\
\hline & & & & 20 & 40 & 60 & 80 & 100 & 200 \\
\hline \multirow[t]{2}{*}{$50 \mathrm{R}-4,87-89 \mathrm{~h}$} & FIG & 2.931 & P & 6.41 & 6.47 & 6.52 & 6.55 & 6.57 & 6.64 \\
\hline & & & S & 3.55 & 3.59 & 3.62 & 3.64 & 3.66 & 3.69 \\
\hline \multirow[t]{2}{*}{$52 \mathrm{R}-4,69-71 \mathrm{~h}$} & FTG & 3.168 & $\mathbf{P}$ & 6.54 & 6.60 & 6.64 & 6.67 & 6.70 & 6.78 \\
\hline & & & s & 3.61 & 3.63 & 3.64 & 3.65 & 3.65 & 3.68 \\
\hline \multirow[t]{2}{*}{$53 \mathrm{R}-3,15-17 \mathrm{~h}$} & FTG & 3.139 & $\mathrm{P}$ & 6.38 & 6.44 & 6.46 & 6.51 & 6.53 & 6.60 \\
\hline & & & S & 3.63 & 3.64 & 3.67 & 3.69 & 3.70 & 3.73 \\
\hline \multirow[t]{2}{*}{$55 \mathrm{R}-3,130-133 \mathrm{~h}$} & FTG & 3.241 & P & 6.62 & 6.67 & 6.71 & 6.73 & 6.75 & 6.81 \\
\hline & & & s & 3.65 & 3.68 & 3.70 & 3.71 & 3.72 & 3.74 \\
\hline \multirow[t]{2}{*}{$56 \mathrm{R}-2,144-146 \mathrm{~h}$} & FIG & 3.169 & $\mathrm{P}$ & 6.04 & 6.13 & 6.19 & 6.23 & 6.26 & 6.35 \\
\hline & & & $\mathrm{S}$ & 3.48 & 3.51 & 3.53 & 3.55 & 3.56 & 3.59 \\
\hline \multirow[t]{2}{*}{$57 \mathrm{R}-2,135-137 \mathrm{~h}$} & OG & 2.900 & $P$ & 6.61 & 6.69 & 6.73 & 6.76 & 6.79 & 6.85 \\
\hline & & & s & 3.77 & 3.79 & 3.81 & 3.82 & 3.83 & 3.85 \\
\hline \multirow[t]{2}{*}{$58 \mathrm{R}-2,33-35 \mathrm{~h}$} & OG & 2.841 & $\mathrm{P}$ & 6.71 & 6.78 & 6.83 & 6.85 & 6.87 & 6.92 \\
\hline & & & $\mathrm{S}$ & 3.68 & 3.72 & 3.74 & 3.76 & 3.77 & 3.80 \\
\hline $59 \mathrm{R}-3,64-69 v$ & OG & 2.913 & P & 6.51 & 6.75 & 6.88 & 6.96 & 7.01 & 7.12 \\
\hline $60 \mathrm{R}-1,18-20 \mathrm{~h}$ & OG & 2.986 & $\mathrm{P}$ & 6.62 & 6.89 & 6.98 & 7.04 & 7.07 & 7.16 \\
\hline $62 \mathrm{R}-3,104-106 \mathrm{~h}$ & OG & 3.013 & $\mathrm{P}$ & 6.70 & 6.81 & 6.87 & 6.92 & 6.94 & 7.01 \\
\hline \multirow{2}{*}{$63 \mathrm{R}-6,28-30 \mathrm{~h}$} & AOG & 2.917 & P & 6.74 & 6.81 & 6.86 & 6.89 & 6.92 & 7.00 \\
\hline & & & $\mathbf{S}$ & 3.77 & 3.81 & 3.83 & 3.85 & 3.86 & 3.90 \\
\hline $65 R-2,67-69 h$ & OG & 2.960 & $\mathrm{P}$ & 6.87 & 6.97 & 7.04 & 7.08 & 7.11 & 7.20 \\
\hline \multirow[t]{2}{*}{$69 \mathrm{R}-4,138-140 \mathrm{~h}$} & OG & 2.970 & P & 6.98 & 7.12 & 7.20 & 7.24 & 7.27 & 7.32 \\
\hline & & & $\mathrm{S}$ & 3.90 & 3.95 & 3.98 & 4.00 & 4.01 & 4.05 \\
\hline $70 \mathrm{R}-1,105-107 \mathrm{~h}$ & AlM & 2.765 & $\mathrm{P}$ & 6.05 & 6.12 & 6.17 & 6.21 & 6.25 & 6.37 \\
\hline $72 \mathrm{R}-3,36-38 \mathrm{~h}$ & OG & 2.997 & P & 6.99 & 7.11 & 7.19 & 7.25 & 7.29 & 7.40 \\
\hline $75 \mathrm{R}-6,75-77 \mathrm{~h}$ & $\mathrm{Mg}$ & 2.937 & P & 6.88 & 6.97 & 7.02 & 7.07 & 7.10 & 7.19 \\
\hline $76 \mathrm{R}-3,50-52 \mathrm{~h}$ & Dia & 2.981 & P & 6.55 & 6.63 & 6.69 & 6.72 & 6.75 & 6.81 \\
\hline $77 \mathrm{R}-3,56-59 \mathrm{~h}$ & $\mathrm{OG}$ & 2.952 & P & 6.64 & 6.72 & 6.77 & 6.81 & 6.84 & 6.91 \\
\hline $77 \mathrm{R}-3,61-66 \mathrm{v}$ & OG & 2.953 & $P$ & 6.74 & 6.83 & 6.89 & 6.92 & 6.95 & 7.00 \\
\hline $77 \mathrm{R}-4,70-72 \mathrm{~h}$ & My & 2.999 & $\mathrm{P}$ & 6.68 & 6.73 & 6.76 & 6.79 & 6.81 & 6.86 \\
\hline & & & Sp & 3.73 & 3.75 & 3.76 & 3.77 & 3.77 & 3.79 \\
\hline $77 \mathrm{R}-4,82-87 v$ & My & 2.971 & $\mathrm{P}$ & 6.66 & 6.75 & 6.80 & 6.83 & 6.86 & 6.92 \\
\hline $78 R-4,65-67 h$ & PM & 2.962 & P & 6.96 & 7.06 & 7.11 & 7.15 & 7.18 & 7.26 \\
\hline $79 \mathrm{R}-7,99-101 \mathrm{~h}$ & $\mathrm{Ga}$ & 2.937 & P & 6.67 & 6.84 & 6.93 & 6.98 & 7.01 & 7.08 \\
\hline $81 \mathrm{R}-7,64-67 \mathrm{~h}$ & OG & 2.978 & $\mathrm{P}$ & 6.91 & 7.02 & 7.09 & 7.14 & 7.17 & 7.24 \\
\hline $82 \mathrm{R}-2,13-15 \mathrm{~h}$ & OG & 2.905 & $\mathrm{P}$ & 6.83 & 6.93 & 6.99 & 7.04 & 7.07 & 7.15 \\
\hline $83 R-4,95-97 h$ & FM & 2.981 & $\mathrm{P}$ & 6.84 & 6.99 & 7.08 & 7.15 & 7.20 & 7.31 \\
\hline & & & $\mathrm{Sp}$ & 3.86 & 3.91 & 3.94 & 3.97 & 3.99 & 4.04 \\
\hline & & & So & 3.81 & 3.86 & 3.89 & 3.91 & 3.92 & 3.96 \\
\hline $83 R-4,100-104 v$ & FM & 2.963 & P & 7.07 & 7.12 & 7.15 & 7.17 & 7.19 & 7.24 \\
\hline $83 \mathrm{R}-7,104-106 \mathrm{~h}$ & $\operatorname{Tr}$ & 3.103 & $\mathrm{P}$ & 6.57 & 6.84 & 6.99 & 7.09 & 7.15 & 7.28 \\
\hline $84 \mathrm{R}-2,67-69 \mathrm{~h}$ & AlG & 2.818 & P & 5.89 & 6.05 & 6.15 & 6.22 & 6.27 & 6.39 \\
\hline & & & $\mathrm{Sp}$ & 3.27 & 3.44 & 3.53 & 3.60 & 3.64 & 3.74 \\
\hline & & & So & 3.17 & 3.28 & 3.35 & 3.39 & 3.42 & 3.50 \\
\hline $84 \mathrm{R}-3,14-16 \mathrm{~h}$ & OG & 2.947 & $\mathrm{P}$ & 6.73 & 6.81 & 6.86 & 6.89 & 6.92 & 6.98 \\
\hline $85 \mathrm{R}-4,9-11 \mathrm{~h}$ & AIG & 2.932 & $\mathrm{P}$ & 6.27 & 6.38 & 6.45 & 6.50 & 6.54 & 6.66 \\
\hline & & & $\mathrm{Sp}$ & 3.64 & 3.70 & 3.74 & 3.77 & 3.79 & 3.86 \\
\hline & & & So & 3.48 & 3.55 & 3.60 & 3.63 & 3.65 & 3.74 \\
\hline $85 R-5,32-36 v$ & PM & 2.884 & P & 6.61 & 6.66 & 6.71 & 6.73 & 6.75 & 6.81 \\
\hline $85 \mathrm{R}-5,41-44 \mathrm{~h}$ & PM & 2.862 & P & 6.77 & 6.85 & 6.90 & 6.93 & 6.97 & 7.07 \\
\hline $85 \mathrm{R}-7,17-19 \mathrm{~h}$ & $\mathrm{Tr}$ & 2.879 & P & 6.59 & 6.75 & 6.83 & 6.88 & 6.91 & 6.98 \\
\hline $86 \mathrm{R}-6,143-145 \mathrm{~h}$ & My & 2.916 & P & 6.46 & 6.58 & 6.65 & 6.71 & 6.75 & 6.88 \\
\hline & & & Sp & 3.62 & 3.67 & 3.71 & 3.73 & 3.74 & 3.78 \\
\hline & & & So & 3.65 & 3.70 & 3.73 & 3.75 & 3.76 & 3.80 \\
\hline $87 \mathrm{R}-5,20-22 \mathrm{~h}$ & My & 3.120 & $\mathrm{P}$ & 6.13 & 6.24 & 6.31 & 6.36 & 6.40 & 6.51 \\
\hline & & & Sp & 3.55 & 3.59 & 3.61 & 3.63 & 3.64 & 3.69 \\
\hline & & & So & 3.46 & 3.51 & 3.54 & 3.56 & 3.58 & 3.64 \\
\hline
\end{tabular}

$\mathrm{P}=$ compressional wave, $\mathrm{h}=$ compressional-wave propagating horizontally, $\mathrm{v}=$ compressional-wave propagating vertically, $\mathrm{S}=$ shear-wave, $\mathrm{Sp}=$ = shear-wave propagating horizontally and vibrating parallel to foliation, So $=$ shear-wave propagating horizontally and vibrating orthogonally to foliation. AIG = altered gabbro, $\mathrm{AlM}=$ altered metagabbro, $\mathrm{AMg}=$ amphibole microgabbro, $\mathrm{AMy}=$ amphibole mylonite, $\mathrm{AnG}=$ anorthositic gabbro, $\mathrm{AOG}=$ amphibole olivine gabbro, $\mathrm{Ba}=$ basalt, $\mathrm{Dia}=$ diabase, $\mathrm{FTG}=\mathrm{Fe}-\mathrm{Ti}$ oxide gabbro, $\mathrm{FM}=$ foliated metagabbro, $\mathrm{Ga}=$ gabbro, $\mathrm{Mg}=$ microgabbro, $\mathrm{MMg}=$ meta-microgabbro, My = mylonite, $\mathrm{PG}=$ porphyroclast gabbro, $\mathrm{PM}=$ porphyroclast metagabbro, $\mathrm{PMy}=$ porphyroclast mylonite, $\mathrm{Tr}=$ troctolite.

nations accurate to approximately $1 \%$. The minicores were prepared with both sides flat and parallel to within $0.008 \mathrm{~cm}$ and having the same dimensions as the shipboard samples (Robinson, Von Herzen, et al., 1989). The samples were jacketed with copper foil to provide an electrical ground for the system, and brass tabs were attached at both ends to serve as conducting surfaces. Acoustic piezoelectric transducers designed for frequencies of $1 \mathrm{MHz}$ were placed on each end of the sample, and rubber tubing was fitted over the assembly to prevent the pressure medium from invading the rock pore spaces (Fig. 1A). This assembly was placed inside a pressure vessel and pressurized hydrostatically up to $200 \mathrm{MPa}$ using a hand pump. Simultaneous electrical pulses were applied to the sending transducer on the sample and a transducer inside a calibrated delay line (Fig. 1B). Both waveforms were displayed on a dual-trace oscilloscope, and the length of the 
A

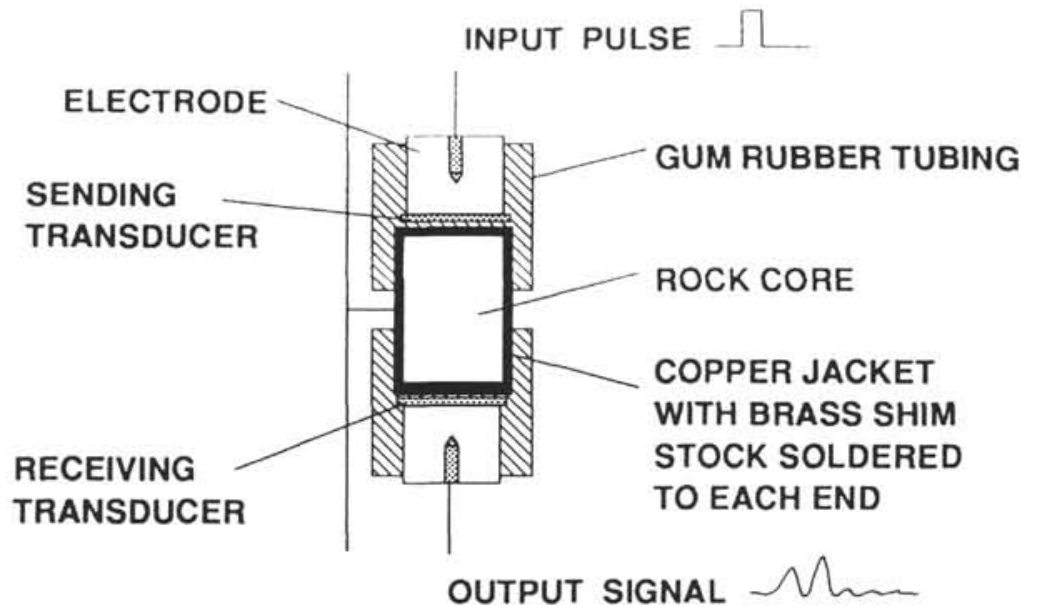

B

PULSE

GENERATOR

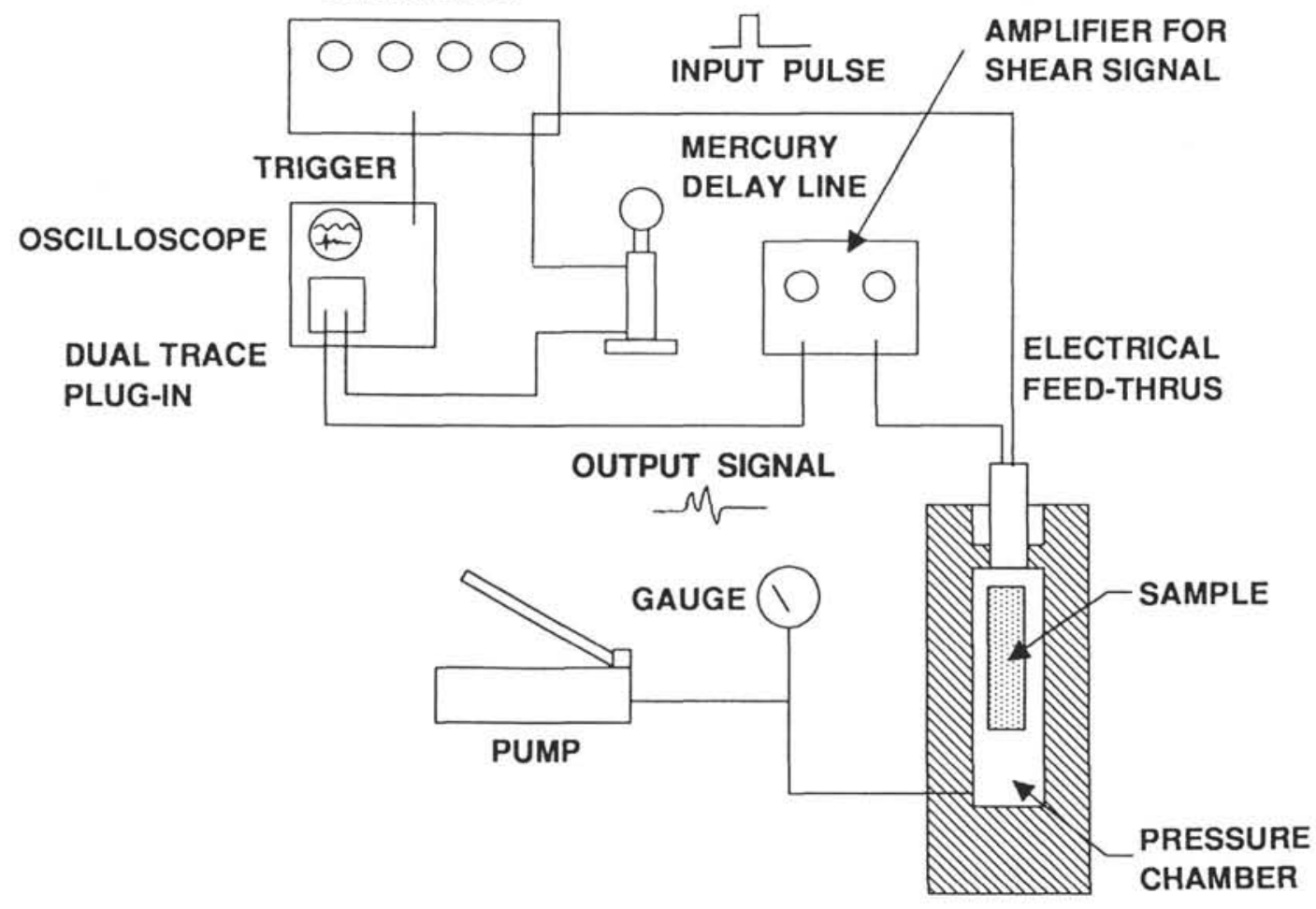

Figure 1. Schematics of the 200-MPa system. A. Sample assembly. B. Assembly for the $200 \mathrm{MPa}$ hand pump system (both after Christensen, 1985).

mercury delay line was adjusted so that the signals were superimposed, implying that the pulse transmission time was the same for the sample and the mercury column. Thus, the sample velocity $(v)$, calculated from the known sample length $(l)$, the length of the mercury column $\left(l_{\mathrm{Hg}}\right)$, and the velocity of mercury $\left(v_{H g}=1.446 \mathrm{~km} / \mathrm{s}\right.$ at $30^{\circ} \mathrm{C}$; Christensen, 1985$)$, is derived by

$$
v=l v_{H g} / l_{H g}
$$

Additional measurements of $V_{p}$ were performed on a small number of water-saturated samples by placing a fine mesh screen between the copper foil and the core to allow the sample to drain during pressurization. For comparison, the results of these measurements are presented in Table 2.

Wet and dry densities, porosities, and water contents for horizontal cores were determined (as part of the shipboard analysis) using a motion-compensated microbalance for measuring mass ( $\pm 0.010 \mathrm{~g}$ accuracy) and a Penta pycnometer for measuring sample volumes $( \pm 0.03 \%)$ in both the saturated and dry states (Robinson, Von Herzen, et al., 1989). Samples were dried at $110 \pm 5^{\circ} \mathrm{C}$ for $24 \mathrm{hr}$ to drive off water. Purge times of 5 min using helium gave bulk densities to an accuracy 
Table 2. Compressional-wave velocities of selected water-saturated samples.

\begin{tabular}{|c|c|c|c|c|c|c|c|c|c|}
\hline \multirow[b]{2}{*}{ Core, section, interval $(\mathrm{cm})$} & \multirow{2}{*}{$\begin{array}{c}\text { Rock }^{\mathrm{a}} \\
\text { type }\end{array}$} & \multirow{2}{*}{$\begin{array}{l}\text { Density } \\
\left(\mathrm{g} / \mathrm{cm}^{3}\right)\end{array}$} & \multirow[b]{2}{*}{ Mode $^{\mathrm{a}}$} & \multicolumn{3}{|c|}{ Velocity $(\mathrm{km} / \mathrm{s})$} & \multicolumn{3}{|c|}{ Pressure (MPa) } \\
\hline & & & & 20 & 40 & 60 & 80 & 100 & 200 \\
\hline $118-735 \mathrm{~B}-14 \mathrm{R}-2,22-25 \mathrm{~h}$ & FM & 2.992 & P & 6.72 & 6.84 & 6.93 & 7.02 & 7.09 & 7.31 \\
\hline 52R-1, 31-33h & FTG & 3.174 & $\mathrm{P}$ & & 6.59 & 6.69 & 6.76 & 6.82 & 6.95 \\
\hline $62 \mathrm{R}-3,130-133 \mathrm{~h}$ & OG & 2.936 & $\mathrm{P}$ & & 6.95 & 7.11 & 7.22 & 7.31 & 7.48 \\
\hline $74 \mathrm{R}-5,44-47 \mathrm{~h}$ & OG & 2.927 & $P$ & 7.01 & 7.12 & 7.18 & 7.22 & 7.25 & 7.35 \\
\hline $77 \mathrm{R}-3,40-43 \mathrm{~h}$ & OG & 2.861 & $\mathrm{P}$ & 6.63 & 6.76 & 6.85 & 6.93 & 6.97 & 7.06 \\
\hline $87 \mathrm{R}-5,38-41 \mathrm{~h}$ & PMy & 2.983 & $\mathrm{P}$ & & 6.35 & 6.46 & 6.54 & 6.60 & 6.72 \\
\hline
\end{tabular}

a See Table 1 for symbols.

of about $2 \%$ or $\pm 0.006 \mathrm{~g} / \mathrm{cm}^{3}$. Interconnected porosities were determined to $\pm 0.2 \%$. Bulk densities for vertical cores were calculated using the measured dimensions and masses of the rock cylinders.

\section{DESCRIBING AND SELECTING SAMPLES FROM HOLE 735B}

The gabbro section of Hole $735 \mathrm{~B}$ was divided into six main lithologic units. To investigate seismic anisotropy, both horizontally and vertically oriented samples relative to the borehole were taken from each of the units. Samples were also selected at specific depths to cover adequately the various textures and mineral assemblages recognized in the drill core. Locations of both horizontal and vertical samples are represented as tic marks in Figure 2. These units were based on primary igneous mineralogy, mineral compositions, and deformation textures and structures (Robinson, Von Herzen, et al., 1989).

The extent and intensity of deformation of the rocks at Hole 735B varies from one lithologic unit to another; both are important for understanding the seismic anisotropy of the section. Both plastic and brittle deformation were observed to varying degrees in many of the samples. Shipboard scientists (Robinson, Von Herzen, et al., 1989) recognized four types of textures produced by plastic deformation, in order of increasing deformation. These are unfoliated or poorly foliated, well-foliated or porphyroclastic, augen gneissic, and mylonitic.

The unfoliated or poorly foliated gabbros are characterized by a slight elongation of pyroxene crystals in an unrecrystallized plagioclase matrix. Well-foliated or porphyroclastic samples have a strong foliation defined by a fabric of the mafic porphyroclasts and by lamellar zones of partial recrystallization of the plagioclase. In these samples, the deformation of the plagioclase $\left(A n_{50-70}\right)$, clinopyroxene, and amphibole porphyroclasts has produced a strong, preferred mineral orientation, in both recrystallized grains and in porphyroclasts of the remaining original grains. The augen gneissic textures have a banded appearance defined by elongated porphyroclasts and alternating layers of mafic minerals that probably represents original grains that have been recrystallized. In the mylonitic gabbros, the well-rounded pyroxene augen and the recrystallized olivine crystals are enclosed in a fine-grained matrix of recrystallized plagioclase and clinopyroxene. Foliation of the metagabbros generally was inclined to the core axis, with apparent dips of $15^{\circ}$ to $45^{\circ}$, decreasing with depth.

\section{DISCUSSION}

In the following discussion, the influence of porosity, density, alteration, mineral orientation, as well as chemical and mineralogical compositions, on the seismic properties of Hole 735B are examined. Elastic constants calculated from measured gabbro velocities and densities are examined in detail. Emphasis on the elastic behavior of lower crustal rocks and its significance on future drilling also are discussed.

\section{Crack Porosity}

As with all shallow oceanic drill holes, fracture porosity is a major factor influencing the velocity structure of Hole 735B. Throughout the core, a large population of small subhorizontal veins and open fractures crosscut a larger set of inclined cracks and faults. This set of microcracks may have developed later, either because of unloading during the uplift of the transverse ridge to the present depth of Hole 735B (Gallo et al., 1987; Robinson, Von Herzen, et al., 1989) or to drilling. As we pointed out previously, open fractures can lower seismic velocities significantly (Adams and Williamson, 1923; Birch and Bancroft, 1938, 1940; Birch, 1961; Hyndman and Drury, 1976). The application of confining pressure closes fractures caused by conventional drilling techniques and also diminishes anisotropy created by the presence of oriented cracks. Thus, low-pressure velocity measurements can offer better estimates of in-situ velocities at Hole 735B than can atmospheric values, while higher pressure measurements can be used to estimate $V_{p}$ under lower crustal conditions.

$V_{p}$ measurements obtained at $200 \mathrm{MPa}$ indicate that seismic velocities decrease with increasing crack porosity for the gabbros of Hole 735B (Fig. 3), even though porosities for most samples are less than $1 \%$. A velocity-porosity plot at $200 \mathrm{MPa}$ follows the same trend as atmospheric measurements (Robinson, Von Herzen, et al., 1989) obtained from shipboard analyses, although the velocities at $200 \mathrm{MPa}$ are considerably faster. Hence, pressure experiments reduce the influence of cracks on seismic velocities. The velocity hysteresis commonly observed in high porosity samples from 10 to $100 \mathrm{MPa}$ (Fig. 4A) also is caused by fractures that close with increasing pressure and do not open completely when pressure is released (Birch, 1961). Samples having low porosities usually exhibit less hysteresis (Fig. 4B). At low pressures, laboratory velocities of vertical and horizontal cores from the same units often show significant anisotropy, whereas at pressures above $100 \mathrm{MPa}$, the rock is typically almost isotropic (Fig. 5). This implies that low pressure measurements in high porosity regions are heavily influenced by the presence of oriented fractures. Therefore, anisotropy (at atmospheric pressures) calculated for samples in these units as part of the shipboard analysis (Kirby et al., 1988; Robinson, Von Herzen, et al., 1989) can reflect the effect of a preferred crack orientation on the velocities. This is especially true in zones of high porosity and permeability, such as those of lithologic Units I and IV.

\section{Density}

A $V_{p}$-density plot for the horizontal cores of Hole $735 \mathrm{~B}$ olivine gabbros and metagabbros shows a clustering of points around a mean $V_{p}=7.10 \mathrm{~km} / \mathrm{s}$ and a mean density $=2.95$ $\mathrm{g} / \mathrm{cm}^{3}$ (Fig. 6). A pressure of $200 \mathrm{MPa}$ was chosen for the 
Depth (mbsf) LEG 118 HOLE 735B

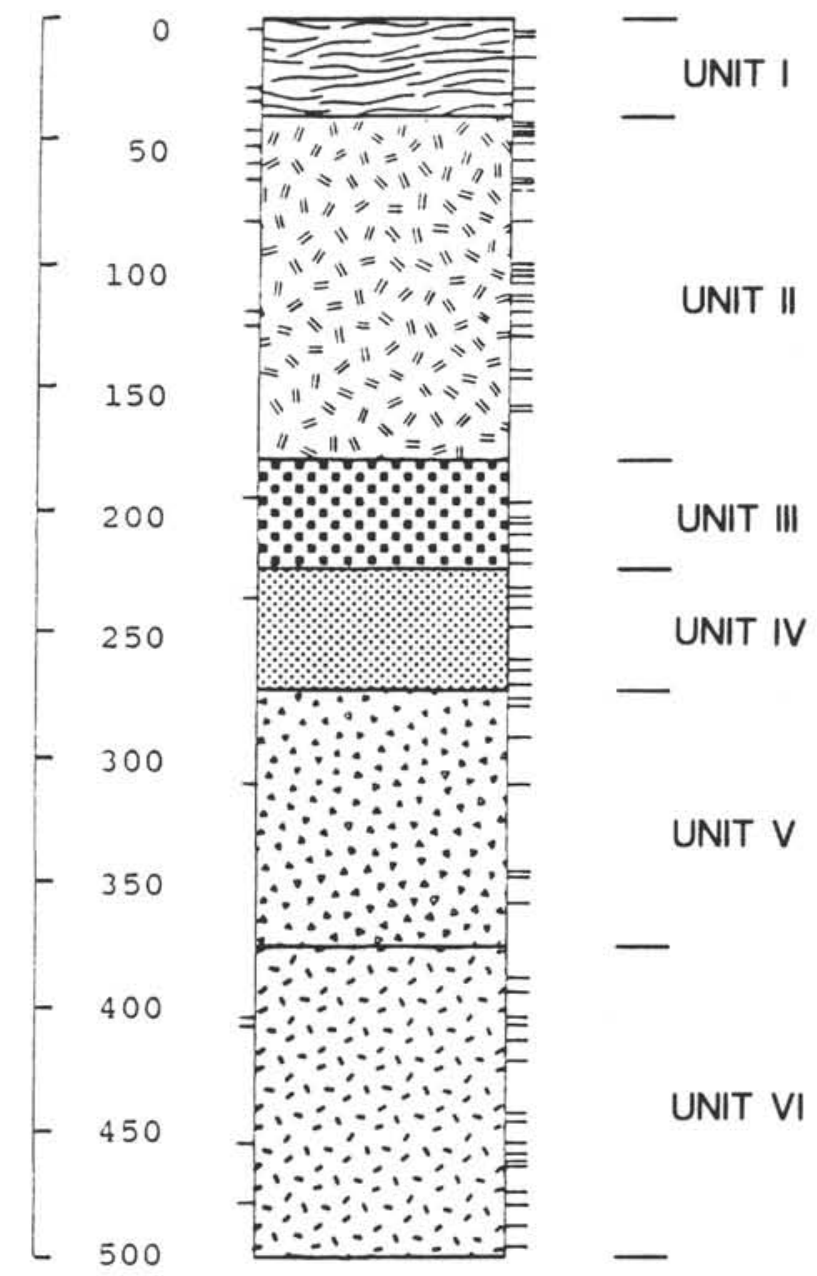

\section{Foliated Metagabbros}

\section{Olivine-bearing and Olivine Gabbros}

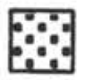
Fe-Ti Oxide Gabbros

\section{Fe-Ti Oxide Gabbros}

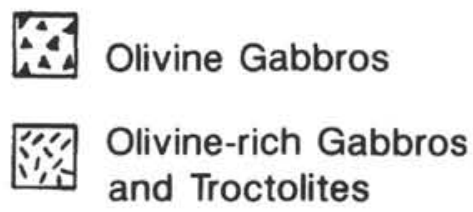

Figure 2. Lithostratigraphic column of Hole 735B. Tic marks at right represent horizontal sample locations (64 samples). Those on left represent vertical sample locations (17 samples).

analysis because the effects of fractures become negligible at this pressure (dry and wet velocities, such as those in Tables 1 and 2, plot in the same velocity-density field). The Fe-Ti oxide gabbros fall in a distinct zone with an average density of $3.20 \mathrm{~g} / \mathrm{cm}^{3}$ and an average compressional-wave velocity of $6.80 \mathrm{~km} / \mathrm{s}$. The densities of the mylonites range from 2.84 to $3.10 \mathrm{~g} / \mathrm{cm}^{3}$, with the variations primarily related to compositional changes between olivine mylonites and $\mathrm{Fe}-\mathrm{Ti}$ oxide mylonites.

The correlation between the density, velocity, and mean atomic weights of the Hole 735B rocks with Birch's law holds up remarkably well. To emphasize the importance of chemical composition on seismic velocities, lines of constant mean atomic weight at 1000 MPA were obtained from Birch (1961), corrected to $200 \mathrm{MPa}$ pressure (Table 3 ), and plotted in the velocity-density diagram (Fig. 6). Iron-free silicates have mean atomic weights near 20 , and the reported mean atomic weight for common rocks is 21 (Birch, 1961). The most common elements that produce deviations from 20 are calcium, iron, and titanium, with increasing iron content causing most of the deviation between 20 and 21 observed in the majority of the gabbros from Hole 735B. The deviation of the $\mathrm{Fe}-\mathrm{Ti}$ oxide gabbros and two mylonites from the $\mathrm{m}=20$ to 21 region indicates a large concentration of iron and titanium. The location of the basalt sample between $m=22$ and $m=23$ is also unusual and will be discussed later. 


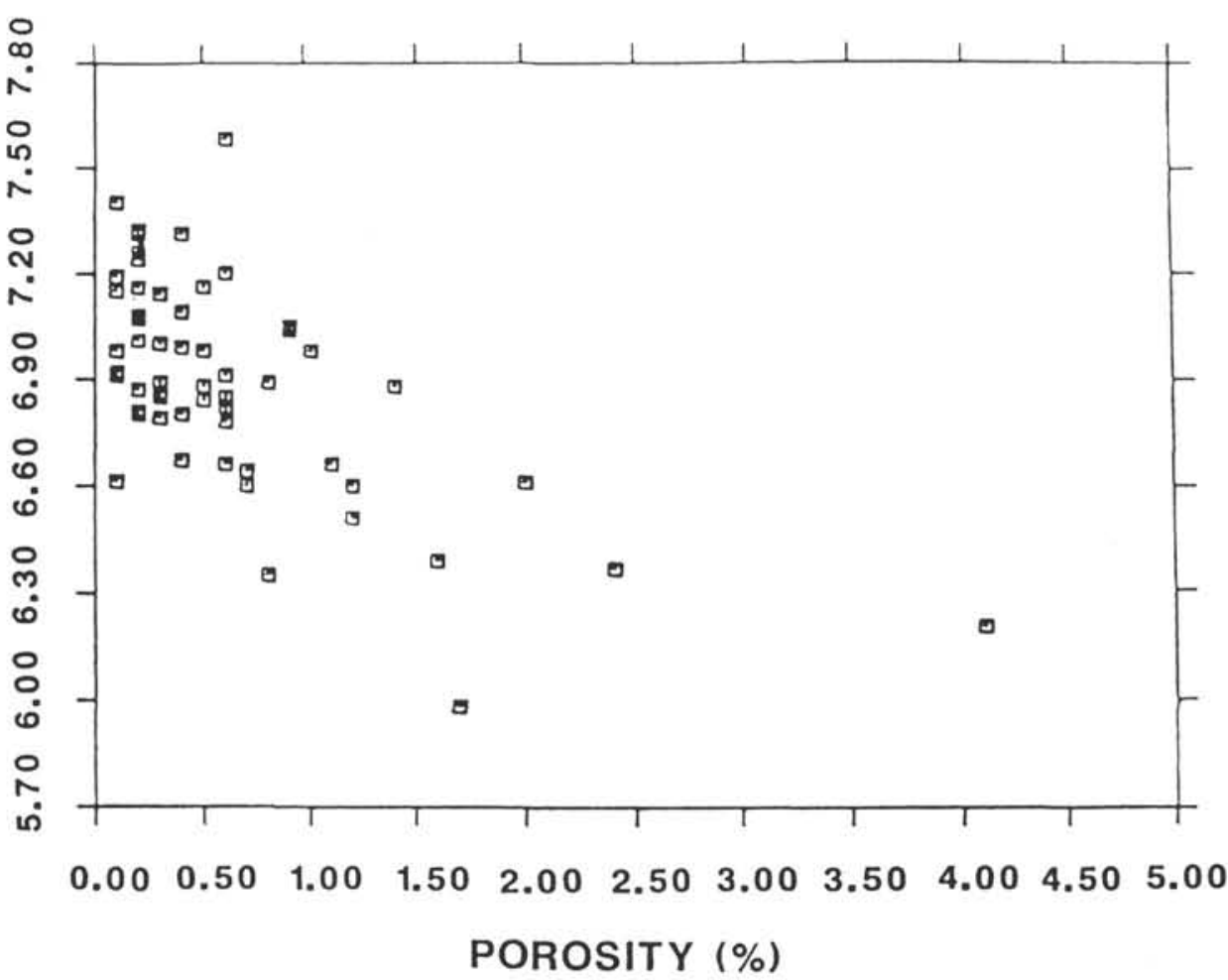

Figure 3. Effect of crack porosity on compressional-wave velocity. Velocities of gabbros measured at $200 \mathrm{MPa}$.

\section{Alteration}

The degree of alteration of the samples recovered from Hole $735 \mathrm{~B}$ correlates with the number of veins and cracks cutting the core. Veins provide the pathways for hydrothermal circulation at temperatures low enough to produce retrograde metamorphic hydration reactions and secondary mineral phases, such as amphiboles and phyllosilicates. Because the amphiboles have properties similar to the pyroxenes they replace, alteration to amphiboles generally leaves the velocities unchanged. The replacement of olivine $\left(V_{p} \approx 8.6 \mathrm{~km} / \mathrm{s}\right)$ by talc $\left(V_{p} \simeq 6.3 \mathrm{~km} / \mathrm{s}\right)$ and magnetite $\left(V_{p} \simeq\right.$ 5.7 to $6.8 \mathrm{~km} / \mathrm{s}$ ) has a significant effect on the compressionalwave velocities of olivine gabbros and metagabbros. The presence of phyllosilicates tends to lower the velocities, and this proves to be an important factor in the velocity structure of Hole 735B.

Velocities and densities were measured in three altered samples from Hole 735B. Two altered metagabbros (Cores 118-735B-70R-1 and 118-735B-84R-2) and the basalt (Core 118-735B-23R-4) are characterized by relatively low densities and compressional-wave velocities, as shown in Figure 6 and Table 1. Densities of the gabbroic samples range from 2.765 to $2.818 \mathrm{~g} / \mathrm{cm}^{3}$, while velocities vary from 6.35 to $6.37 \mathrm{~km} / \mathrm{s}$ (Fig. 6). Examination of thin sections (Robinson, Von Herzen, et al., 1989) reveals that these samples have large percentages $(15 \%-17 \%)$ of phyllosilicates, which accounts for the low values of $V_{p}$ and low densities. The basalt sample contains $5 \%$ talc and $16 \%$ clay minerals after olivine and clinopyroxenes. Hence, observations of these samples emphasize the importance of the correlation between seismic properties and the amount of phyllosilicates in Hole 735B.

\section{Mineralogy}

Even though most undeformed oceanic rocks contain large percentages of highly anisotropic minerals, they tend to be isotropic, or nearly isotropic, because of the random orientation of their main mineral constituents. Velocities for a mineral aggregate having a random orientation can be calculated from the minerals' elastic constants. Voigt and Reuss averages (Voigt, 1928; Reuss, 1929) assume uniform strain and stress, respectively, and give high and low limits for the aggregate velocity. Usually, the VRH average, which is the mean of the Voigt and Reuss averages (Hill, 1952), is used as the velocity for a monomineralic rock having random mineral orientation (Birch, 1961). The gabbros of Hole 735B having random mineral orientation should fall in a triangular field defined by the VRH averages of the main mineral constituents.

A velocity-density plot at $200 \mathrm{MPa}$ (Fig. 7A) indicates that the seismic properties of the unaltered olivine gabbros fall in a region controlled by the $\mathrm{VRH}$ of plagioclase $\left(\mathrm{An}_{56}\right)$, olivine, and augite (Christensen, 1982). As we pointed out earlier (Robinson, Von Herzen, et al., 1989), the velocity-density data are consistent with the average mineral proportions in these olivine gabbros (60:40 plagioclase:augite; up to $30 \%$ olivine). Pyroxene gabbros (i.e., Core 118-735B-60R-1) and gabbros having secondary amphiboles (i.e., Core 118-735B-58R-2) also fall in this region. These results imply that there is no apparent mineral orientation that would cause $V_{p}$ anisotropy. In addition, examination of thin sections of the olivine and olivine-bearing gabbros commonly found in Units II and V shows random orientation and distinct igneous textures, supporting the previous observations.

The Fe-Ti oxide gabbros, commonly found in Units III and IV, fall in a different field that is defined by the VRH averages 

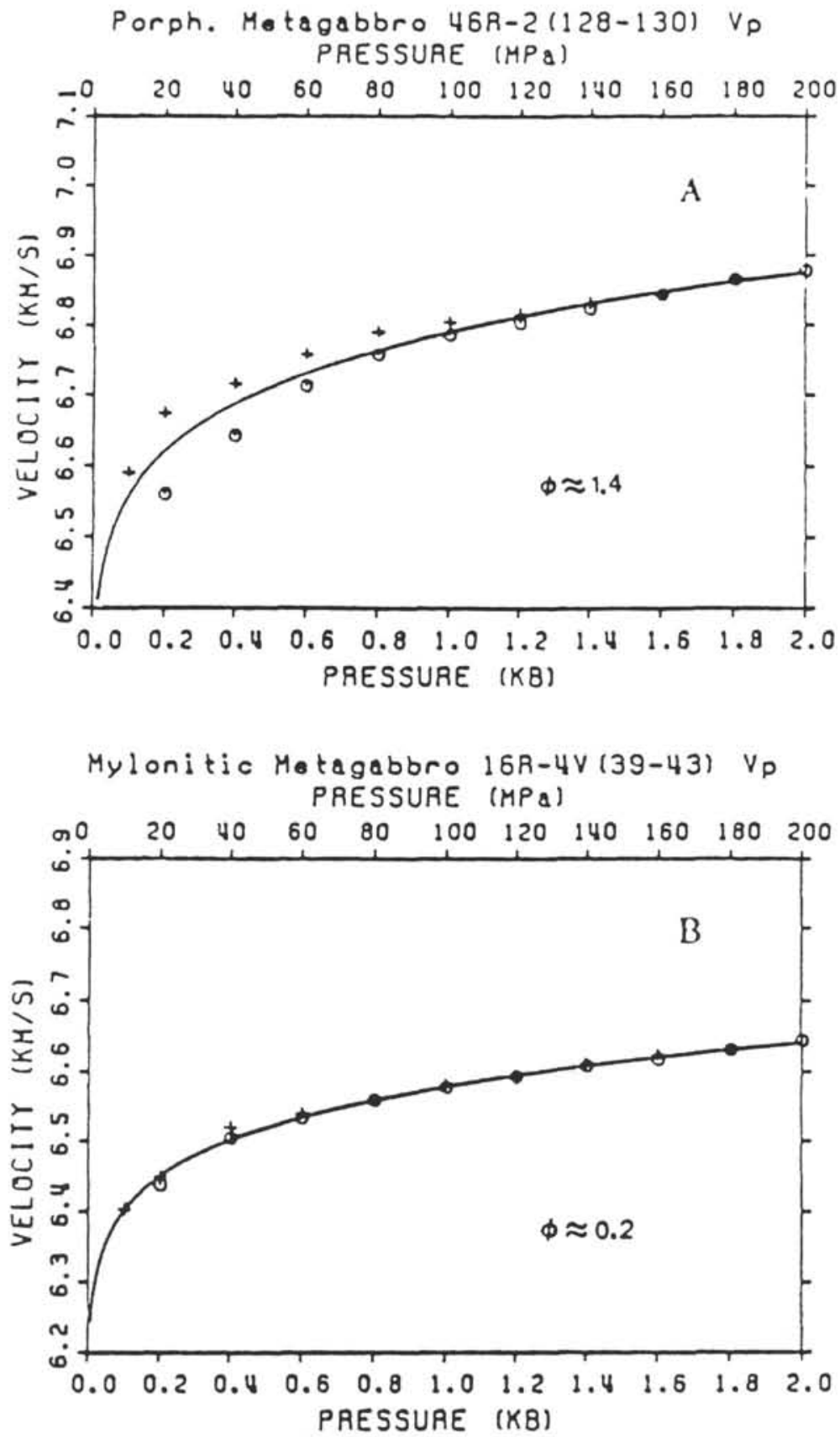

Figure 4. Effect of crack porosity on compressional-wave velocity as a function of confining pressure. A. High porosity-high hysteresis between measured as pressure values increases (circles) and as pressure decreases (pluses). B. Low porosity-low hysteresis.

for plagioclase, augite, and magnetite (Fig. 7B). Hence, in the absence of a preferred mineral orientation, the aggregate velocities of both the olivine and oxide gabbros can be explained in terms of the VRH averages.

\section{Anisotropy}

Many of the deformed gabbros exhibit significant $V_{p}$ anisotropy (Table 1). Oriented plagioclase, amphibole, and clinopyroxene, as well as banding, are possible causes of this anisotropy. Velocities of many of the deformed samples fall outside the isotropic plagioclase-olivine-augite field, as shown in Figure 8. Plagioclase $\left(\mathrm{An}_{56}\right) V_{p}$ data for the [010] and [100] crystallographic directions also fall outside this area. This suggests that some of the metagabbros of Hole 735B have varying degrees of anisotropy as a result of preferred plagioclase orientation, confirming some results of room-pressure directional $V_{p}$ measurements of saturated cube-shaped samples reported earlier (Robinson, Von Herzen, et al., 1989).

Thin-section observations (Fig. 9) confirm that $V_{p}$ of some of the metagabbros are affected by oriented tabular plagioclase with [010] subhorizontal cleavage. This orientation produces fast velocities vertically along the [010] direction (perpendicular to the cleavage) and slower velocities normal to the [010] direction. In Figure 10A, the $V_{p}$ anisotropy of Core 118-735B-40R-5 


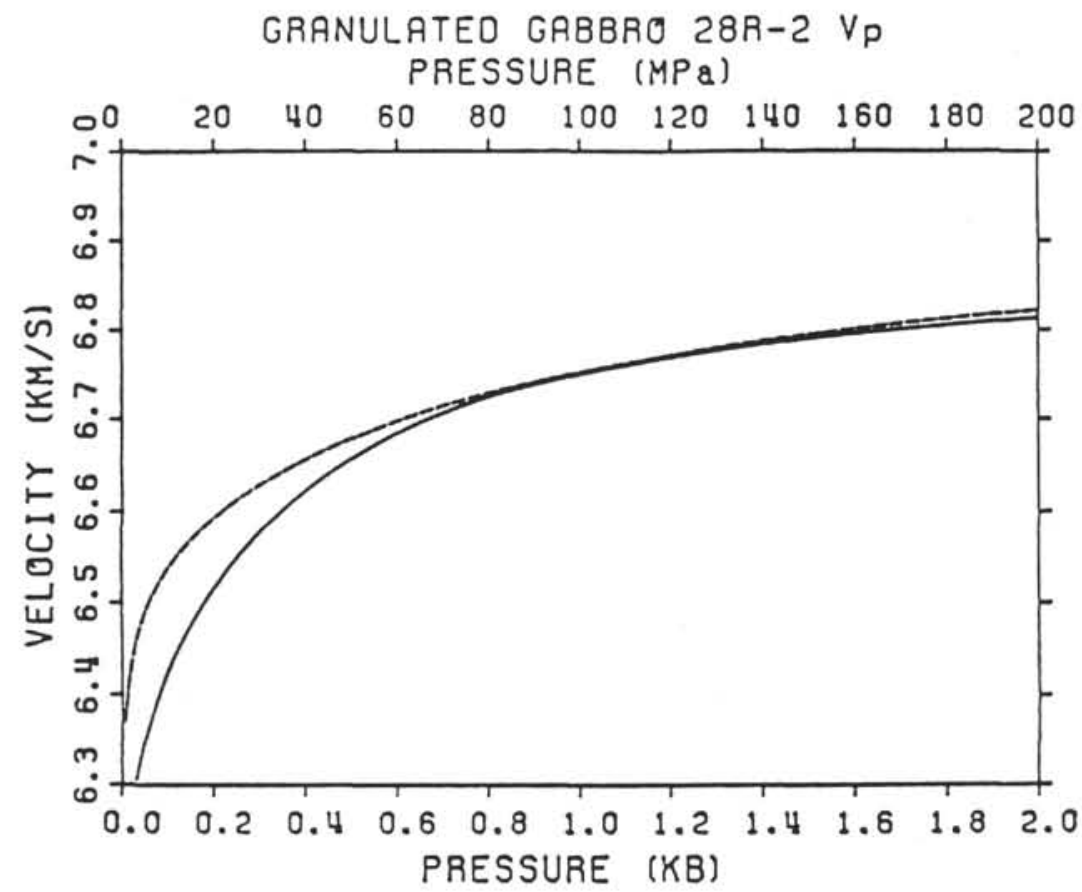

Figure 5. Effect of crack porosity at low pressures between vertical (solid line) and horizontal (dashed line) cores. Possible cause of anisotropy at low pressures is oriented cracks.

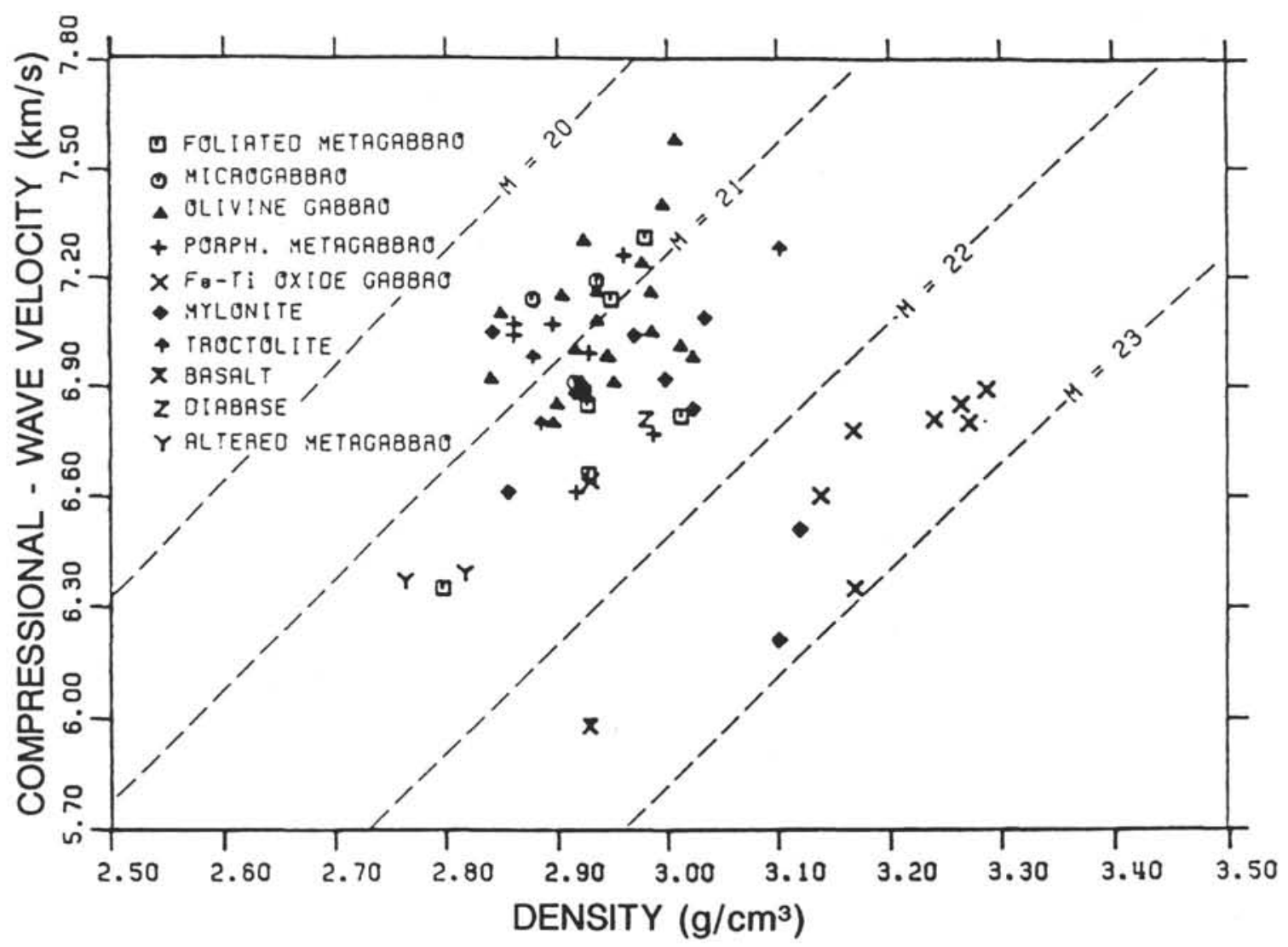

Figure 6. Velocity-density systematics for different rock types of Hole 735B. Measurements were taken at $200 \mathrm{MPa}$ to minimize the effect of crack porosity. Dashes represent lines of constant mean atomic weight, based on Birch's law. 
Table 3. Parameters used for calculating the lines of constant mean atomic weight at $200 \mathrm{MPa}$ (from Birch, 1961).

\begin{tabular}{cccc}
\hline Average MAW & $a(\mathrm{~km} / \mathrm{s})$ & $a_{c}(\mathrm{~km} / \mathrm{s})$ & $b\left[\mathrm{~km} / \mathrm{s} \times\left(\mathrm{g} / \mathrm{cm}^{3}\right)^{-1}\right]$ \\
\hline 20 & -1.423 & -1.603 & 3.169 \\
21 & -1.520 & -1.700 & 2.988 \\
22 & -2.123 & -2.303 & 2.929 \\
23 & -3.723 & -3.903 & 2.974 \\
\hline
\end{tabular}

Note: These parameters were obtained from a least-squares solution of the form,

$$
V_{p}=a+\rho b
$$

where $V_{p}$ in $\mathrm{km} / \mathrm{s}$ at $200 \mathrm{MPa}, \rho$ in $\mathrm{g} / \mathrm{cm}^{3}, a=$ the velocity intercept for velocities at $1000 \mathrm{MPa}$ (Birch, 1961), $a_{c}=$ the corrected intercept for velocities at $200 \mathrm{MPa}$, and $b=$ the slope of the lines.

increases from $0 \%$ to approximately $4 \%$ at $200 \mathrm{MPa}$. At low pressures, microcracks counteract preferred mineral orientation and produce low anisotropy values. However, at higher pressures, microcracks are closed, and the effect of plagioclase orientation is enhanced. Augite porphyroclasts also exhibit a tendency toward orientation, with (100) normal to foliation and [100] parallel to lineation, which would cause velocities normal to these directions to be slower than the VRH average of augite.

Fine-grained mylonites having large concentrations of amphiboles also have significant $V_{p}$ anisotropy (approximately $6 \%$ ), as shown in Figure 10B. Thin-section observations (Fig. 11) suggest that the high degree of anisotropy may be attributed to oriented amphiboles. This causes horizontal $V_{p}$ to be faster than vertical $V_{p}$, which is the opposite of the plagioclase orientation.

In addition to oriented cracks and minerals, anisotropy may originate from layering in the augen gneissic gabbros and the well-foliated metagabbros. For the most part, these coarse-grained banded mylonites do not exhibit significant variations in compressional-wave velocities, but instead show a large degree of shear-wave splitting. An explanation for the apparent $V_{p}$ isotropy is that because of our sampling procedures, velocities were measured in two orthogonal directions, which were neither parallel nor perpendicular to the layering. This orientation produced intermediate velocities, and no appreciable anisotropy was observed. However, shear-wave splitting has been observed in these samples. This is illustrated in a study of Sample 118-735B-2D-1, 113-115 cm. For this core, transducers were rotated from $0^{\circ}$ (parallel to foliation) to $90^{\circ}$ (perpendicular to foliation). As the vibration angle increases, the delay time between waves also increases, while the amplitude of the waveforms decreases (Fig. 12). The time delay represents shear-wave splitting, which produces $V_{s}$ anisotropy of up to $7 \%$ for a single propagation direction.

Finally, some of the apparent anisotropy in Table 1 can be attributed to differences in mineralogy and texture between the vertical and horizontal cores. Frequent compositional changes with depth throughout Hole $735 \mathrm{~B}$ produce considerable differences in densities and velocities between relatively close-spaced samples (i.e., Cores 118-735B-9D-1, 118-735B-14R-1, 118-735B-20R-2, and 118-735B-28R-1). Therefore, these variations cannot be interpreted in terms of anisotropy.

Although anisotropy within the upper mantle has been studied extensively and attributed to olivine orientation (Hess, 1964; and Francis, 1969), anisotropy within the lower oceanic crust is not well understood. In the case of Hole 735B, the orientation of plagioclase, clinopyroxene, and amphiboles as well as layering are the principal causes for the observed anisotropy. Anisotropy resulting from oriented amphiboles has been observed previously in refraction data from the Pacific Ocean basin off the coast of British Columbia and in laboratory measurements (Christensen, 1972). By contrast, the effects of plagioclase orientation and layering have not been reported previously as explanations for seismic anisotropy in the oceanic crust. These results are significant because of the possibility of finding the same situation in other fracture zones and perhaps even in portions of the lower oceanic crust. However, while these mechanisms can explain the observed anisotropy, one should also point out that because of the complexity of this area, further studies, such as petrofabric analyses, should be performed to fully understand the implications of these findings.

\section{Elastic Constants}

$V_{p} / V_{s}$ ratios, Poisson's ratios $(\sigma)$, bulk moduli $(K)$, and shear moduli $(\mu)$ calculated at selected pressures from measured densities and velocities for various samples are given in Table 4. The elastic moduli computed here apply only to isotropic solids; hence, some caution is advised when using values for the anisotropic rocks (Table 1). These values are important for engineering considerations. In a general way, rock fracture strength is proportional to elastic moduli, where preexisting microfractures reduce the elastic stiffnesses and serve as sources for macroscopic failure by fracturing under the drill bit. This can assist scientists when making loadpressure decisions and bit selections, and may also allow them to estimate better the life span of a core bit when drilling in fracture zones or the lower oceanic crust.

The $V_{p} / V_{s}$ ratio is a parameter widely used by seismologists for interpreting seismic data. A $V_{p}-V_{s}$ plot at $200 \mathrm{MPa}$ (Fig. 13) shows that most of the isotropic samples from Hole 735B fall in a region bounded by lines of constant Poisson's ratio that range from 0.25 to 0.30 (average $\simeq 0.28$ ). This corresponds to $V_{p} / V_{s}$ ratios from 1.76 to 1.85 , with an average value of 1.81 . These values may be helpful for interpreting field data when both $V_{p}$ and $V_{s}$ are known.

\section{SUMMARY}

Measurements of porosity, density, $V_{p}$, and $V_{s}$ from samples collected from (Leg 118) Hole 735B reveal the following conclusions regarding the seismic properties of fracture zone gabbros and the nature of the lower oceanic crust:

1. Crack porosity within the gabbros of Hole $735 \mathrm{~B}$ tends to reduce seismic velocities at low pressures, even though the porosities for most samples are on the order of tenths of a percent. At higher pressures, velocities are primarily related to mineralogy.

2. The olivine gabbros have high average compressionalwave velocities $(7.10 \mathrm{~km} / \mathrm{s}$ at $200 \mathrm{MPa})$ and densities $(\simeq 2.95$ $\mathrm{g} / \mathrm{cm}^{3}$ ). Gabbros having randomly oriented amphiboles display similar velocities.

3. The Fe-Ti oxide gabbros have average densities of 3.20 $\mathrm{g} / \mathrm{cm}^{3}$ and average seismic velocities of $6.80 \mathrm{~km} / \mathrm{s}$. Lower velocities are attributed to the presence of Fe-Ti oxides and the absence of olivine. The presence of alteration products, such as phyllosilicates, also lowers seismic velocities.

4. The seismic properties of the unaltered olivine gabbros fall in a triangular field that is controlled by the VRH averages of their main mineral constituents (plagioclase-olivine-augite). The seismic properties of the $\mathrm{Fe}-\mathrm{Ti}$ oxide gabbros fall in a region defined by the VRH averages of plagioclase, olivine, and magnetite. These findings and observations of thin sections suggest that there is no apparent preferred mineral orientation.

5 . Orientations of plagioclase, clinopyroxene, and amphibole are responsible for $V_{p}$ anisotropy in deformed gabbros. 
Observations of thin sections and deviations from the plagioclase-olivine-augite VRH field confirm these orientations.

6. The layering within many of the metagabbros may produce shear-wave splitting. The effect of the layering on $V_{p}$ is not clear.

7. The Poisson and $V_{p} / V_{s}$ ratios of the isotropic gabbros from Hole $735 \mathrm{~B}$ average 0.28 and 1.81 , respectively.

\section{ACKNOWLEDGMENTS}

We thank the following people for their assistance: W. Wepfer, R. Von Herzen, and two unknown reviewers for their thoughtful comments and discussions. D. Ballotti and G. Soto helped with the laboratory measurements and preparation of this manuscript. In addition, we thank JOI-USSAC and the Office of Naval Research (Contract No. N000014-89-J-1209) for their financial support.

\section{REFERENCES}

Adams, L. H., and Williamson, E. D., 1923. The compressibility of minerals and rocks at high pressures. J. Franklin Inst., 195:475529.

Birch, F., 1960. The velocity of compressional waves in rocks to 10 kilobars, Part 1. J. Geophys. Res., 65:1083-1102. 1961. The velocity of compressional waves in rocks to 10 kilobars, Part 2. J. Geophys. Res., 66:2199-2224.

Birch, F., and Bancroft, D., 1938. The effect of pressure on the rigidity of rocks. J. Geol, 46:59-87 and 113-141.

1940. New measurements of the rigidity of rocks at high pressures. J. Geol., 48:752-766.

Christensen, N. I., 1965. Compressional wave velocities in metamorphic rocks at pressures to 10 kilobars. J. Geophys. Res., 70:61476164.

1972. Seismic anisotropy in the lower oceanic crust. Nature, 237:450-451.

1982. Seismic velocities. In Carmichael, R. S. (Ed.), Handbook of Physical Properties of Rocks, 2: Boca Raton, FL (CRC Press), 1-228.

1985. Measurements of Dynamic Properties of Rock at Elevated Temperatures and Pressures: Philadelphia (Am. Soc. for Testing and Material), 93-107.
Francis, T.J.G., 1969. Generation of seismic anisotropy in the upper mantle along the mid-oceanic ridges. Nature, 221:161-165.

Gallo, D. G., Dick, H.J.B., Schouten, H., Berg, H., and Patriat, P., 1987. The Atlantis II fracture zone. EOS Trans. Am. Geophys. Union, 68:408.

Hess, H. H., 1964. Seismic anisotropy of the uppermost mantle under oceans. Nature, 203:629- -631.

Hill, R., 1952. The elastic behavior of a crystalline aggregate. Proc. Phys. Soc. London, A, 65:349-354.

Hyndman, R. D., and Drury, M. J., 1976. The physical properties of oceanic basement rocks from deep sea drilling on the Mid-Atlantic Ridge at $23^{\circ}$ N. J. Geophys. Res., 81:4042-4059.

Kirby, S. H., Iturrino, G. J., Swift, S. A., Goldberg D., and Leg 118 Scientific Party, 1988. Compressional-wave velocities $\mathrm{Vp}$ and densities at Hole 735B, ODP Leg 118: evidence for $\mathrm{VpH} / \mathrm{VpV}$ anisotropy in layer 3 gabbroic rocks. EOSTrans. Am. Geophys. Union, 69:1402.

Reuss, A., 1929. Berechnung der Fliessgrenze von Mischkristallen auf Grund der Plastizitatsbedingung fur Einkristalle, Z. Angew. Math. Mech., 9:49-58.

Robinson, P. T., Von Herzen, R. P., et al., 1989. Proc. ODP, Init. Repts., 118: College Station, TX (Ocean Drilling Program).

Shearer, P., and Orcutt, J., 1985. Anisotropy in the oceanic lithosphere-theory and observations from Ngendei seismic refraction experiment in the south-west Pacific. Geophys. J. R. Astr. Soc., $80: 493-526$.

1986. Compressional and shear wave anisotropy in the oceanic lithosphere-the Ngendei seismic refraction experiment. Geophys. J. R. Astr. Soc., 87:967-1003. Stephen, R. A., 1981. Seismic anisotropy observed in the oceanic crust. Geophys. Res. Lett., 8:865-868.

Voigt, W., 1928. Lehrbuch der Kristallphysik: Leipzig (B. G. Teulner).

White, R. S., and Whitmarsh, R. B., 1984. An investigation of seismic anisotropy due to cracks in the upper oceanic crust at $45^{\circ} \mathrm{N}$, Mid-Atlantic Ridge. Geophys. J. R. Astr. Soc., 79:439-467.

Date of initial receipt: 11 July 1989

Date of acceptance: 24 February 1989

Ms 118B-151 

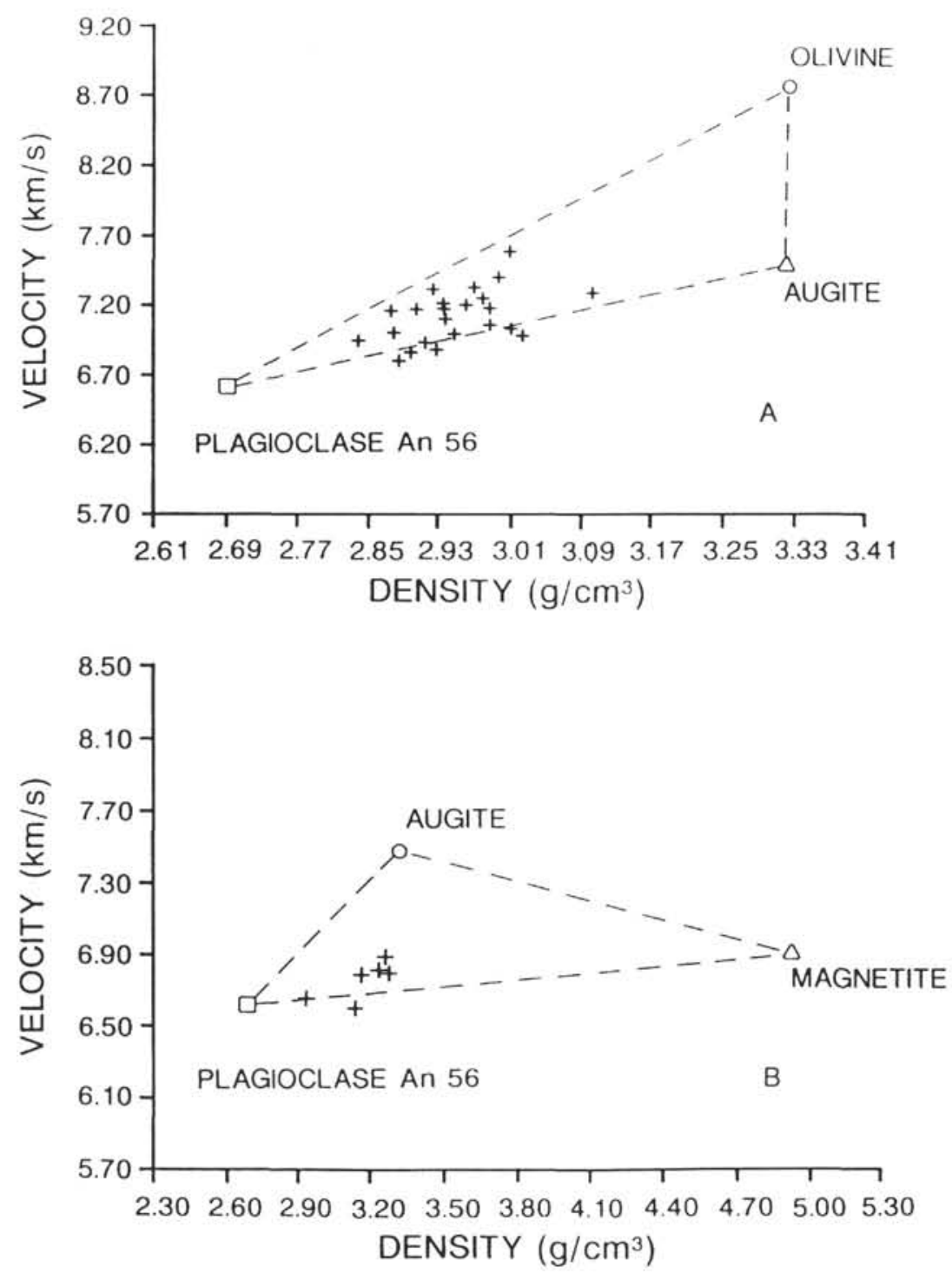

Figure 7. Velocity-density systematics of samples from Hole 735B, expressed in terms of the VRH averages of the major mineral constituents (plag-ol-cpx-magn). A. Relationships for olivine gabbros. B. Fe-Ti oxide gabbros. 


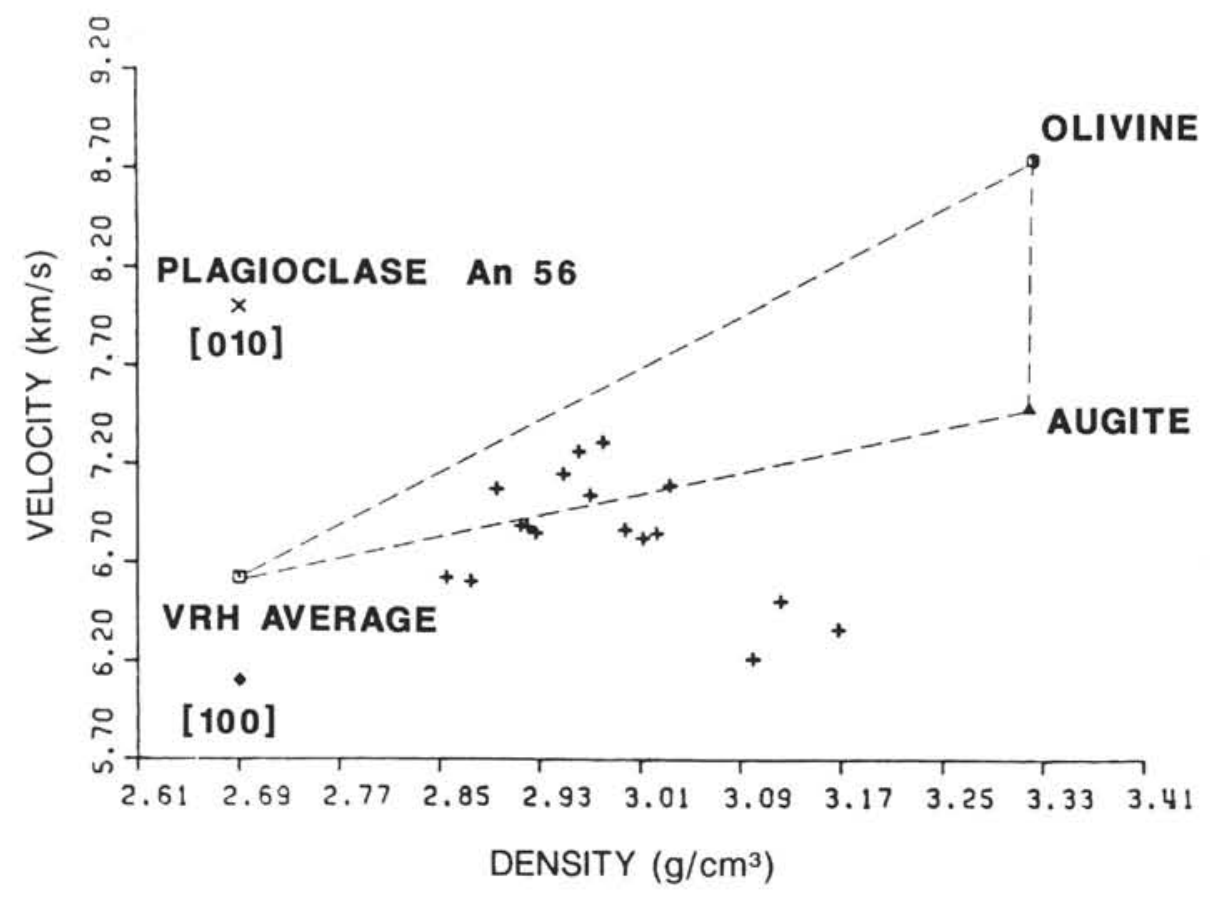

Figure 8. Velocity-density systematics of deformed rocks, using the VRH averages of plagioclase-olivine-clinopyroxene as end-members. The directions of maximum [010] and minimum [100] velocity of plagioclase also are shown to indicate the possibility of anisotropy because of the orientation of the plagioclase.

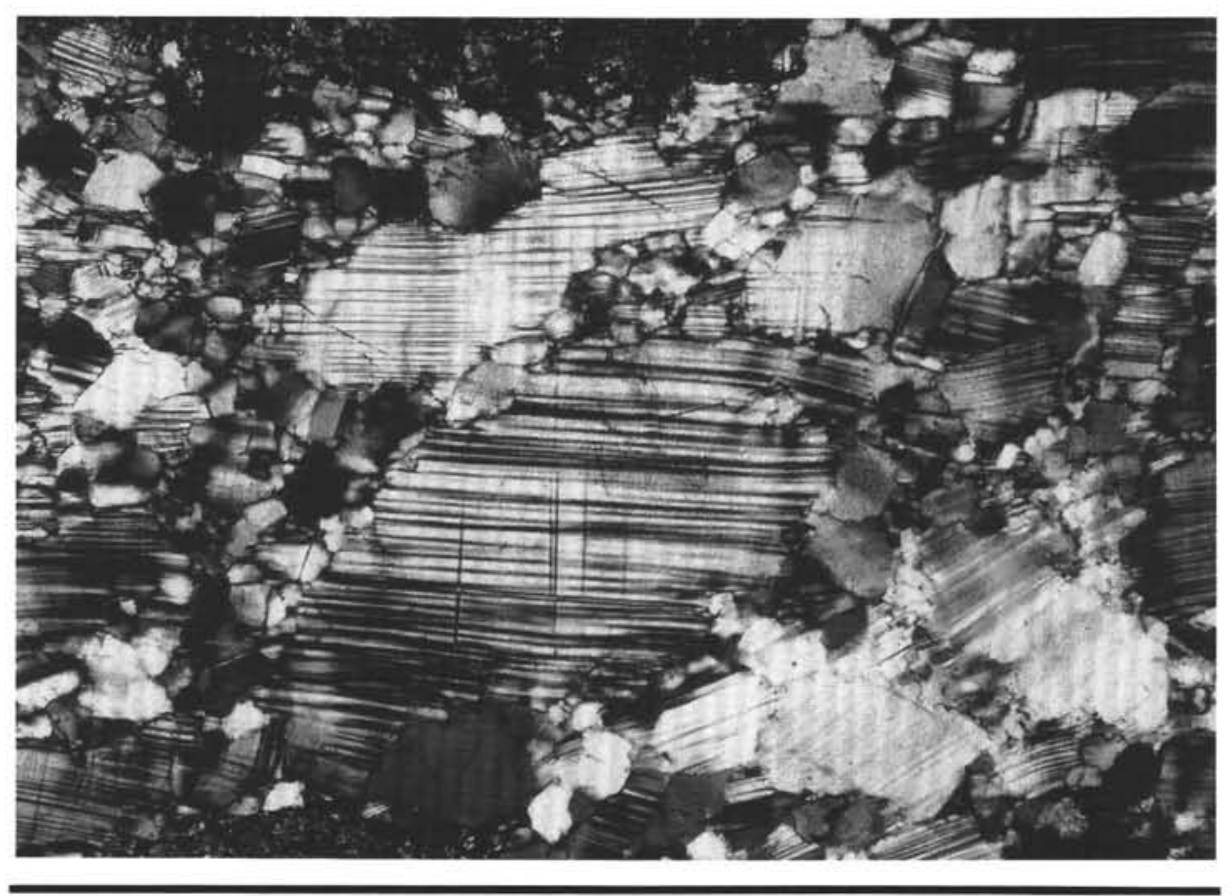

\section{$2.45 \mathrm{~mm}$}

Figure 9. Photomicrograph showing the systematic orientation of plagioclase within some of the deformed metagabbros. Much of the cleavage is oriented subhorizontally. This orientation tends to produce velocities that are fast vertically and slow horizontally at elevated pressures. 

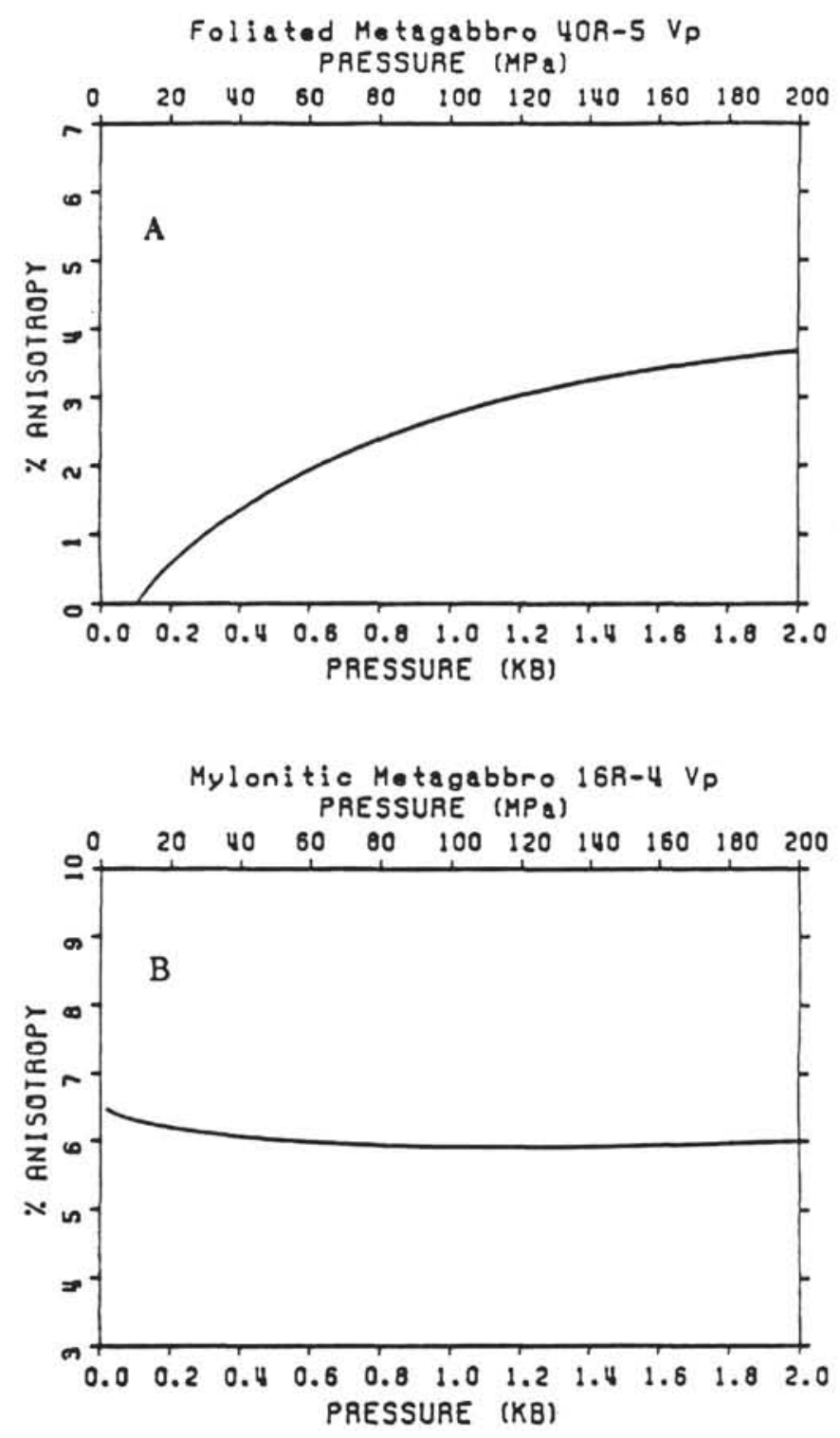

Figure 10. Percentage of anisotropy vs. pressure for (A) oriented plagioclase and (B) oriented amphiboles. 


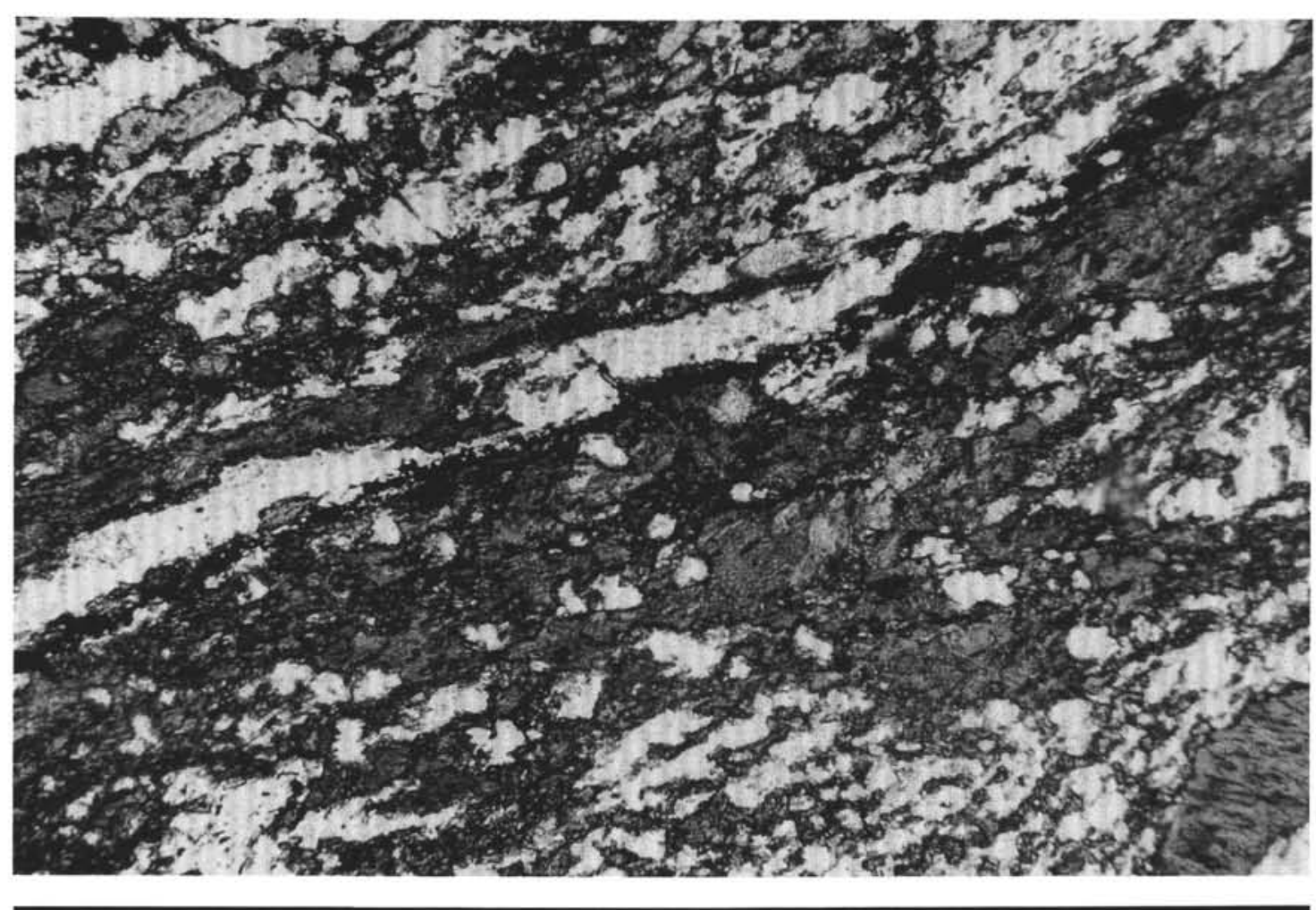

\section{$2.45 \mathrm{~mm}$}

Figure 11. Photomicrograph of Sample 118-735B-16R-4, 24-26 cm, showing oriented amphiboles within some of the metagabbros.

WAVEFORM AT $200 \mathrm{MPa}$

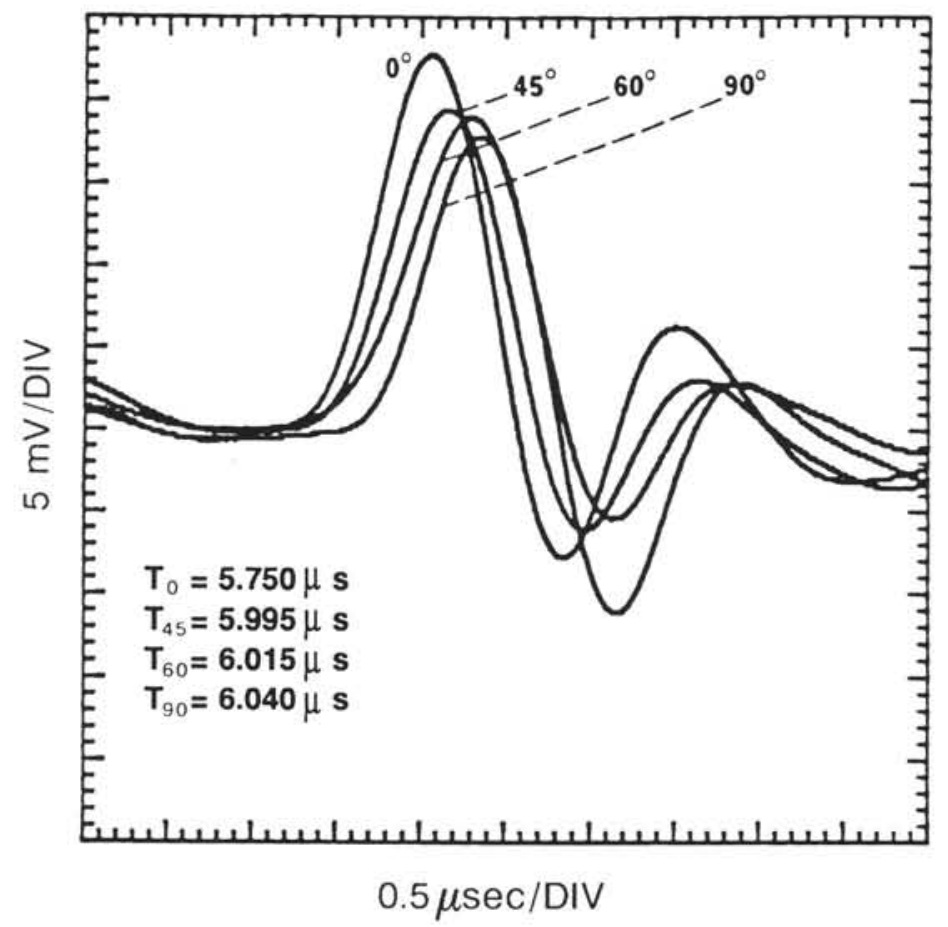

Figure 12. Shear-wave splitting observed in Sample 118-735B-2D-1, 113$115 \mathrm{~cm}$. The time delay between both waves was obtained by rotating the transducers $0^{\circ}, 45^{\circ}, 60^{\circ}$, and $90^{\circ}$ with respect to the foliation. First arrivals are also shown. 
Table 4. Average compressional- and shear-wave velocities and elastic constants for Atlantis II Fracture Zone gabbros.

\begin{tabular}{|c|c|c|c|c|c|c|c|}
\hline Core, section, interval $(\mathrm{cm})$ & $\begin{array}{c}P \\
(\mathrm{~kb})\end{array}$ & $\begin{array}{c}V_{p} \\
(\mathrm{~km} / \mathrm{s})\end{array}$ & $\begin{array}{c}V_{s} \\
(\mathrm{~km} / \mathrm{s})\end{array}$ & $V_{p} / V_{s}$ & $\sigma$ & $\underset{(\mathrm{Mb})}{K}$ & $\stackrel{\mu}{\mu}$ \\
\hline \multirow{8}{*}{$\begin{array}{l}118-735 \mathrm{~B}-23 \mathrm{R}-2, \mathrm{~s}^{34-36} \\
\quad \rho=2.93 \mathrm{~g} / \mathrm{cm}^{3} \\
\phi=0.5 \% \\
\text { Olivine gabbro, } 4 \% \text { ol, } 53 \% \\
\text { plag, } 34 \% \mathrm{cpx}, 8 \% \text { amph, } \\
1 \% \text { ps }\end{array}$} & 0.1 & 6.74 & 3.71 & 1.81 & 0.28 & 0.79 & 0.41 \\
\hline & 0.2 & 6.83 & 3.74 & 1.82 & 0.28 & 0.82 & 0.41 \\
\hline & 0.4 & 6.93 & 3.78 & 1.83 & 0.29 & 0.85 & 0.42 \\
\hline & 0.6 & 7.00 & 3.80 & 1.84 & 0.29 & 0.87 & 0.42 \\
\hline & 0.8 & 7.04 & 3.82 & 1.85 & 0.29 & 0.89 & 0.43 \\
\hline & 1.0 & 7.08 & 3.83 & 1.85 & 0.29 & 0.90 & 0.43 \\
\hline & 1.5 & 7.13 & 3.85 & 1.85 & 0.29 & 0.91 & 0.44 \\
\hline & 2.0 & 7.15 & 3.86 & 1.85 & 0.29 & 0.92 & 0.44 \\
\hline \multirow{8}{*}{$\begin{array}{l}118-735 \mathrm{~B}-26 \mathrm{R}-1,62-64 \\
\quad \rho=2.93 \mathrm{~g} / \mathrm{cm}^{3} \\
\phi=0.2 \% \\
\text { Altered olivine gabbro, } 2 \% \\
\text { ol, } 50 \% \text { plag, } 31 \% \text { amph, } \\
10 \% \mathrm{ps}, 5 \% \mathrm{cpx}, 2 \% \text { ox }\end{array}$} & 0.1 & 6.53 & 3.73 & 1.75 & 0.26 & 0.71 & 0.41 \\
\hline & 0.2 & 6.60 & 3.76 & 1.76 & 0.26 & 0.72 & 0.41 \\
\hline & 0.4 & 6.69 & 3.80 & 1.76 & 0.26 & 0.74 & 0.42 \\
\hline & 0.6 & 6.74 & 3.83 & 1.76 & 0.26 & 0.76 & 0.43 \\
\hline & 0.8 & 6.77 & 3.85 & 1.76 & 0.26 & 0.77 & 0.43 \\
\hline & 1.0 & 6.80 & 3.87 & 1.76 & 0.26 & 0.77 & 0.44 \\
\hline & 1.5 & 6.84 & 3.89 & 1.76 & 0.26 & 0.78 & 0.44 \\
\hline & 2.0 & 6.87 & 3.90 & 1.76 & 0.26 & 0.79 & 0.45 \\
\hline \multirow{8}{*}{$\begin{array}{l}118-735 \mathrm{~B}-42 \mathrm{R}-4,62-64 \\
\rho=2.92 \mathrm{~g} / \mathrm{cm}^{3} \\
\phi=0.6 \% \\
\text { Olivine gabbro, } 16 \% \text { ol, } 55 \% \\
\text { plag, } 25 \% \mathrm{cpx}, 3 \% \text { amph, } \\
\text { ps }<1 \% \text { ox }<1 \%\end{array}$} & 0.1 & 6.62 & 3.76 & 1.76 & 0.26 & 0.73 & 0.41 \\
\hline & 0.2 & 6.68 & 3.79 & 1.76 & 0.26 & 0.74 & 0.42 \\
\hline & 0.4 & 6.75 & 3.83 & 1.76 & 0.26 & 0.76 & 0.43 \\
\hline & 0.6 & 6.80 & 3.86 & 1.76 & 0.26 & 0.77 & 0.44 \\
\hline & 0.8 & 6.83 & 3.87 & 1.76 & 0.26 & 0.78 & 0.44 \\
\hline & 1.0 & 6.85 & 3.88 & 1.76 & 0.26 & 0.79 & 0.44 \\
\hline & 1.5 & 6.88 & 3.90 & 1.77 & 0.26 & 0.79 & 0.45 \\
\hline & 2.0 & 6.90 & 3.91 & 1.77 & 0.26 & 0.80 & 0.45 \\
\hline \multirow{8}{*}{$\begin{array}{l}118-735 \mathrm{~B}-46 \mathrm{R}-2,{ }^{2} 21-23 \\
\rho=2.99 \mathrm{~g} / \mathrm{cm}^{3} \\
\phi=0.9 \% \\
\text { Olivine-bearing Gabbro, } 3 \% \\
\text { ol, } 70 \% \text { plag, } 26 \% \mathrm{cpx} \\
\text { amph }<1 \%, \text { ox }<1 \%\end{array}$} & 0.1 & 6.76 & 3.75 & 1.80 & 0.28 & 0.80 & 0.42 \\
\hline & 0.2 & 6.81 & 3.79 & 1.80 & 0.28 & 0.82 & 0.43 \\
\hline & 0.4 & 6.88 & 3.83 & 1.80 & 0.28 & 0.83 & 0.44 \\
\hline & 0.6 & 6.92 & 3.85 & 1.80 & 0.28 & 0.84 & 0.44 \\
\hline & 0.8 & 6.95 & 3.87 & 1.80 & 0.28 & 0.85 & 0.45 \\
\hline & 1.0 & 6.98 & 3.88 & 1.80 & 0.28 & 0.86 & 0.45 \\
\hline & 1.5 & 7.02 & 3.89 & 1.80 & 0.28 & 0.87 & 0.45 \\
\hline & 2.0 & 7.05 & 3.90 & 1.80 & 0.28 & 0.88 & 0.45 \\
\hline \multirow{3}{*}{$\begin{array}{l}118-735 \mathrm{~B}-48 \mathrm{R}-4 \mathrm{~s}^{82-84} \\
\rho=3.27 \mathrm{~g} / \mathrm{cm}^{3} \\
\phi=0.8 \%\end{array}$} & 0.1 & 6.54 & 3.70 & 1.77 & 0.26 & 0.80 & 0.45 \\
\hline & 0.2 & 6.61 & 3.74 & 1.77 & 0.26 & 0.82 & 0.46 \\
\hline & 0.4 & 6.68 & 3.78 & 1.77 & 0.27 & 0.84 & 0.47 \\
\hline \multirow{5}{*}{$\begin{array}{l}\text { Fe-Ti Oxide Grabbo, } 1 \% \text { ol, } \\
48 \% \text { plag, } 30 \% \text { cpx, } 12 \% \\
\text { ox, } 5 \% \text { amph, } 3 \% \text { ps, } 1 \% \\
\text { opx }\end{array}$} & 0.6 & 6.73 & 3.81 & 1.77 & 0.27 & 0.85 & 0.47 \\
\hline & 0.8 & 6.76 & 3.82 & 1.77 & 0.27 & 0.86 & 0.48 \\
\hline & 1.0 & 6.79 & 3.84 & 1.77 & 0.27 & 0.87 & 0.48 \\
\hline & 1.5 & 6.84 & 3.86 & 1.77 & 0.27 & 0.88 & 0.49 \\
\hline & 2.0 & 6.89 & 3.87 & 1.78 & 0.27 & 0.90 & 0.49 \\
\hline \multirow{8}{*}{$\begin{array}{l}\text { 118-735B-50R- } 4,87-89 \\
\quad \rho=2.93 \mathrm{~g} / \mathrm{cm}^{3} \\
\phi=0.7 \% \\
\text { Fe-Ti Oxide Gabbro, } 73 \% \\
\text { plag, } 15 \% \text { cpx, } 6 \% \text { ox, } 5 \% \\
\text { amph, } 1 \% \text { ps }\end{array}$} & 0.1 & 6.35 & 3.51 & 1.81 & 0.28 & 0.70 & 0.36 \\
\hline & 0.2 & 6.41 & 3.54 & 1.81 & 0.28 & 0.71 & 0.37 \\
\hline & 0.4 & 6.47 & 3.59 & 1.80 & 0.28 & 0.72 & 0.38 \\
\hline & 0.6 & 6.51 & 3.62 & 1.80 & 0.28 & 0.73 & 0.38 \\
\hline & 0.8 & 6.55 & 3.64 & 1.80 & 0.28 & 0.74 & 0.39 \\
\hline & 1.0 & 6.57 & 3.65 & 1.80 & 0.28 & 0.74 & 0.39 \\
\hline & 1.5 & 6.61 & 3.68 & 1.80 & 0.28 & 0.75 & 0.40 \\
\hline & 2.0 & 6.64 & 3.69 & 1.80 & 0.28 & 0.76 & 0.40 \\
\hline \multirow{3}{*}{$\begin{array}{l}118-735 \mathrm{~B}-52 \mathrm{R}-4_{\mathrm{g}} 69-71 \\
\rho=3.17 \mathrm{~g} / \mathrm{cm}^{3} \\
\phi=0.6 \%\end{array}$} & 0.1 & 6.49 & 3.59 & 1.81 & 0.28 & 0.79 & 0.41 \\
\hline & 0.2 & 6.54 & 3.61 & 1.81 & 0.28 & 0.81 & 0.41 \\
\hline & 0.4 & 6.60 & 3.63 & 1.82 & 0.28 & 0.83 & 0.42 \\
\hline \multirow{5}{*}{$\begin{array}{l}\text { Fe-Ti Oxide Gabbro, } 38 \% \\
\text { plag, } 38 \% \text { cpx, } 15 \% \text { ox, } \\
8 \% \text { amph, } 1 \% \text { ps }\end{array}$} & 0.6 & 6.64 & 3.64 & 1.83 & 0.29 & 0.84 & 0.42 \\
\hline & 0.8 & 6.67 & 3.65 & 1.83 & 0.29 & 0.85 & 0.42 \\
\hline & 1.0 & 6.69 & 3.65 & 1.83 & 0.29 & 0.86 & 0.42 \\
\hline & 1.5 & 6.74 & 3.67 & 1.84 & 0.29 & 0.87 & 0.43 \\
\hline & 2.0 & 6.78 & 3.68 & 1.84 & 0.29 & 0.89 & 0.43 \\
\hline \multirow{3}{*}{$\begin{array}{l}118-735 \mathrm{~B}-55 \mathrm{R}-4{ }_{3} 130-133 \\
\rho=3.24 \mathrm{~g} / \mathrm{cm}^{3} \\
\phi=0.2 \%\end{array}$} & 0.1 & 6.57 & 3.63 & 1.81 & 0.28 & 0.83 & 0.43 \\
\hline & 0.2 & 6.62 & 3.65 & 1.81 & 0.28 & 0.84 & 0.43 \\
\hline & 0.4 & 6.67 & 3.68 & 1.81 & 0.28 & 0.86 & 0.44 \\
\hline
\end{tabular}


Table 4 (continued).

\begin{tabular}{|c|c|c|c|c|c|c|c|}
\hline Core, section, interval (cm) & $\begin{array}{c}P \\
(\mathrm{~kb})\end{array}$ & $\begin{array}{c}V_{p} \\
(\mathrm{~km} / \mathrm{s})\end{array}$ & $\begin{array}{c}V_{s} \\
(\mathrm{~km} / \mathrm{s})\end{array}$ & $V_{p} / V_{s}$ & $\sigma$ & $\begin{array}{c}K \\
(\mathrm{Mb})\end{array}$ & $\begin{array}{c}\mu \\
(\mathrm{Mb})\end{array}$ \\
\hline \multirow{5}{*}{$\begin{array}{l}\text { Fol. Fe-Ti Oxide Gabbro, } \\
4 \% \text { ol, } 55 \% \text { plag, } 25 \% \\
\text { cpx, } 10 \text { ox, } 5 \% \text { amph, } 1 \% \\
\text { opx. }\end{array}$} & 0.6 & 6.71 & 3.69 & 1.82 & 0.28 & 0.87 & 0.44 \\
\hline & 0.8 & 6.73 & 3.71 & 1.82 & 0.28 & 0.88 & 0.45 \\
\hline & 1.0 & 6.75 & 3.72 & 1.82 & 0.28 & 0.88 & 0.45 \\
\hline & 1.5 & 6.78 & 3.73 & 1.82 & 0.28 & 0.89 & 0.45 \\
\hline & 2.0 & 6.81 & 3.74 & 1.82 & 0.28 & 0.90 & 0.45 \\
\hline \multirow{3}{*}{$\begin{array}{l}118-735 \mathrm{~B}-57 \mathrm{R}-2,134-138 \\
\rho=2.91 \mathrm{~g} / \mathrm{cm}^{3} \\
\phi=0.3 \%\end{array}$} & 0.1 & 6.55 & 3.75 & 1.75 & 0.26 & 0.70 & 0.41 \\
\hline & 0.2 & 6.61 & 3.77 & 1.75 & 0.26 & 0.72 & 0.41 \\
\hline & 0.4 & 6.68 & 3.79 & 1.76 & 0.26 & 0.74 & 0.42 \\
\hline \multirow{5}{*}{$\begin{array}{l}\text { Olivine-bearing Gabbro, } 2 \% \\
\text { ol, } 54 \% \text { plag, } 15 \% \text { cpx, } \\
16 \% \text { amph, } 12 \% \text { ps, } 1 \% \\
\text { ox }\end{array}$} & 0.6 & 6.73 & 3.81 & 1.77 & 0.26 & 0.76 & 0.42 \\
\hline & 0.8 & 6.76 & 3.82 & 1.77 & 0.27 & 0.77 & 0.42 \\
\hline & 1.0 & 6.78 & 3.82 & 1.77 & 0.27 & 0.77 & 0.43 \\
\hline & 1.5 & 6.82 & 3.84 & 1.78 & 0.27 & 0.78 & 0.43 \\
\hline & 2.0 & 6.84 & 3.84 & 1.78 & 0.27 & 0.79 & 0.43 \\
\hline \multirow{3}{*}{$\begin{aligned} & 118-735 \mathrm{~B}-58 \mathrm{R}-2,{ }^{3} 3-35 \\
& \rho=2.84 \mathrm{~g} / \mathrm{cm}^{3} \\
& \phi=0.1 \%\end{aligned}$} & 0.1 & 6.65 & 3.65 & 1.82 & 0.28 & 0.75 & 0.38 \\
\hline & 0.2 & 6.71 & 3.68 & 1.82 & 0.29 & 0.77 & 0.38 \\
\hline & 0.4 & 6.78 & 3.72 & 1.83 & 0.29 & 0.78 & 0.39 \\
\hline \multirow{5}{*}{$\begin{array}{l}\text { Olivine Gabbro, } 10 \% \text { ol, } \\
77 \% \text { plag, } 6 \% \text { amph, } 5 \% \\
\text { cpx, } 2 \% \text { ox }\end{array}$} & 0.6 & 6.82 & 3.74 & 1.83 & 0.29 & 0.79 & 0.40 \\
\hline & 0.8 & 6.85 & 3.75 & 1.82 & 0.29 & 0.80 & 0.40 \\
\hline & 1.0 & 6.87 & 3.76 & 1.82 & 0.29 & 0.80 & 0.40 \\
\hline & 1.5 & 6.90 & 3.78 & 1.82 & 0.29 & 0.81 & 0.41 \\
\hline & 2.0 & 6.92 & 3.79 & 1.82 & 0.29 & 0.82 & 0.41 \\
\hline \multirow{3}{*}{$\begin{aligned} & 118-735 \mathrm{~B}-63 \mathrm{R}-6,{ }^{2} 28-30 \\
& \rho=2.91 \mathrm{~g} / \mathrm{cm}^{3} \\
& \phi=0.3 \%\end{aligned}$} & 0.1 & 6.68 & 3.74 & 1.78 & 0.27 & 0.75 & 0.41 \\
\hline & 0.2 & 6.74 & 3.77 & 1.79 & 0.27 & 0.77 & 0.41 \\
\hline & 0.4 & 6.81 & 3.81 & 1.79 & 0.27 & 0.79 & 0.42 \\
\hline \multirow{5}{*}{$\begin{array}{l}\text { Amph. Olivine Gabbro, } 4 \% \\
\text { ol, } 50 \% \text { plag, } 35 \% \text { amph, } \\
10 \% \text { cpx, ps }<1 \% \text {, ox }< \\
1 \%\end{array}$} & 0.6 & 6.86 & 3.83 & 1.79 & 0.27 & 0.80 & 0.43 \\
\hline & 0.8 & 6.89 & 3.85 & 1.7 & 0.27 & 0.81 & 0.43 \\
\hline & 1.0 & 6.91 & 3.86 & 1.79 & 0.27 & 0.81 & 0.43 \\
\hline & 1.5 & 6.96 & 3.88 & 1.79 & 0.27 & 0.83 & 0.44 \\
\hline & 2.0 & 6.99 & 3.89 & 1.80 & 0.28 & 0.84 & 0.44 \\
\hline \multirow{3}{*}{$\begin{array}{l}118-735 \mathrm{~B}-69 \mathrm{R}-4,138-140 \\
\rho=2.97 \mathrm{~g} / \mathrm{cm}^{3} \\
\phi=0.2 \%\end{array}$} & 0.1 & 6. & 3. & 1. & 0.27 & 0.81 & 0.44 \\
\hline & 0.2 & 6. & & 1. & 0.27 & 0.84 & 0.45 \\
\hline & 0.4 & 7.12 & 3.95 & 1.80 & 0.28 & 0.89 & 0.46 \\
\hline \multirow{5}{*}{$\begin{array}{l}\text { Olivine Gabbro, } 8 \% \text { ol, } 55 \% \\
\text { plag, } 35 \% \text { cpx, } 2 \% \text { amph, } \\
\text { ox }<1 \%\end{array}$} & 0.6 & 7.19 & & 1. & 0.28 & 0.91 & 0.47 \\
\hline & 0.8 & 7.24 & 4.00 & 1.81 & 0.28 & 0.92 & 0.47 \\
\hline & 1.0 & 7.26 & 401 & 1.81 & 0.28 & 0.93 & 0.48 \\
\hline & 1.5 & 7.30 & 4.03 & 1.81 & 0.28 & 0.94 & 0.48 \\
\hline & 2.0 & 7.31 & 4.04 & 1.81 & 0.28 & 0.94 & 0.49 \\
\hline \multirow{3}{*}{$\begin{aligned} 118-735 \mathrm{~B}-83 \mathrm{R}-4, & 95-97 \\
\rho & =2.98 \mathrm{~g} / \mathrm{cm}^{3} \\
\phi & =0.2 \%\end{aligned}$} & 0.1 & 6.7 & 3. & 1. & 0. & 0.77 & 0.4 \\
\hline & 0.2 & 6.84 & 3.83 & 1.78 & 0.27 & 0.81 & 0.44 \\
\hline & 0.4 & 6.9 & & 1.8 & 0.28 & 0.86 & 0.45 \\
\hline \multirow{5}{*}{$\begin{array}{l}\text { Porph. Olivine Metagabbro, } \\
15 \% \text { ol, } 50 \% \text { plag, } 32 \% \\
\text { cpx, } 2 \% \text { amph, } 1 \% \text { ox, tr } \\
\text { ps. }\end{array}$} & 0.6 & 7.08 & 3.91 & 1.81 & 0.28 & 0.89 & 0.46 \\
\hline & 0.8 & 7.15 & 3.9 & 1.8 & 0.28 & 0.91 & 0.46 \\
\hline & 1.0 & 7.19 & 3.9 & 1.82 & 0.28 & 0.92 & 0.47 \\
\hline & 1.5 & 7.26 & 3.9 & 1.8 & 0.29 & 0.94 & 0.47 \\
\hline & 2.0 & 7.30 & 4.00 & 1.83 & 0.29 & 0.96 & 0.48 \\
\hline
\end{tabular}

Note: alt $=$ altered, amph $=$ amphiboles or amphibolitized, $\mathrm{cpx}=$ clinopyroxenes, fol $=$ foliated, $\mathrm{ol}=$ olivine, $\mathrm{opx}=$ orthopyroxenes, $\mathrm{ox}=$ oxides, $\mathrm{plag}=$ plagioclase, porph $=$ porphyroclastic, $\mathrm{ps}=$ phyllosilicates, $\mathrm{tr}=$ trace.

Equations used for calculating the elastic constants are as follows:

$$
\begin{aligned}
& \text { Poisson's ratio, } \sigma=\left(V_{p}^{2}-2 V_{s}^{2}\right) /\left[2\left(V_{p}^{2}-V_{s}^{2}\right)\right] \text {. } \\
& \text { Bulk modulus } K=\rho\left[V_{p}^{2}-(4 / 3) V_{s}^{2}\right] \text {. } \\
& \text { Shear modulus, } \mu=\rho V_{s}^{2} \text {. }
\end{aligned}
$$


G. J. ITURRINO, N. I. CHRISTENSEN, S. KIRBY, M. H. SALISBURY

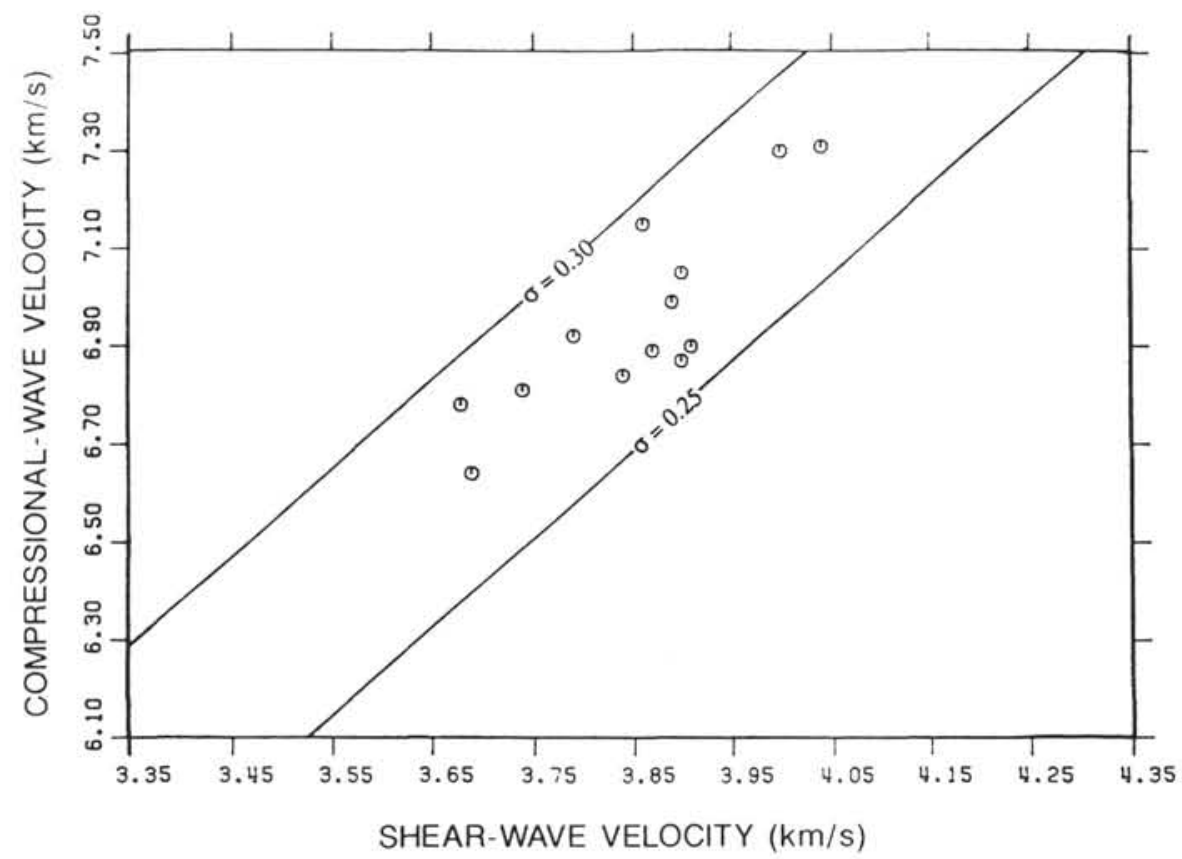

Figure 13. Compressional- and shear-wave velocities at $200 \mathrm{MPa}$ for isotropic gabbros. Solid lines represent constant Poisson's ratio. 